\title{
Dryland ecohydrology and climate change: critical issues and technical advances
}

\author{
L. Wang ${ }^{1,2}$, P. D’Odorico ${ }^{3}$, J. P. Evans ${ }^{4}$, D. J. Eldridge ${ }^{5}$, M. F. McCabe ${ }^{1}$, K. K. Caylor ${ }^{6}$, and E. G. King ${ }^{7}$ \\ ${ }^{1}$ Water Research Center, School of Civil and Environmental Engineering, University of New South Wales, Sydney, \\ NSW, 2052, Australia \\ ${ }^{2}$ Department of Earth Sciences, Indiana University-Purdue University, Indianapolis (IUPUI), Indianapolis, \\ Indiana 46202, USA \\ ${ }^{3}$ Department of Environmental Sciences, University of Virginia, Charlottesville, VA 22904, USA \\ ${ }^{4}$ Climate Change Research Centre, University of New South Wales, Sydney, NSW, 2052, Australia \\ ${ }^{5}$ School of Biological, Earth and Environmental Sciences, University of New South Wales, Sydney, NSW, 2052, Australia \\ ${ }^{6}$ Department of Civil and Environmental Engineering, Princeton University, Princeton, NJ, 08544, USA \\ ${ }^{7}$ Odum School of Ecology and Warnell School of Forestry \& Natural Resources, University of Georgia, Athens, \\ GA, 30602, USA
}

Correspondence to: L. Wang (w.lixin@gmail.com)

Received: 2 April 2012 - Published in Hydrol. Earth Syst. Sci. Discuss.: 16 April 2012

Revised: 13 July 2012 - Accepted: 18 July 2012 - Published: 9 August 2012

\begin{abstract}
Drylands cover about $40 \%$ of the terrestrial land surface and account for approximately $40 \%$ of global net primary productivity. Water is fundamental to the biophysical processes that sustain ecosystem function and food production, particularly in drylands where a tight coupling exists between ecosystem productivity, surface energy balance, biogeochemical cycles, and water resource availability. Currently, drylands support at least 2 billion people and comprise both natural and managed ecosystems. In this synthesis, we identify some current critical issues in the understanding of dryland systems and discuss how arid and semiarid environments are responding to the changes in climate and land use. The issues range from societal aspects such as rapid population growth, the resulting food and water security, and development issues, to natural aspects such as ecohydrological consequences of bush encroachment and the causes of desertification. To improve current understanding and inform upon the needed research efforts to address these critical issues, we identify some recent technical advances in terms of monitoring dryland water dynamics, water budget and vegetation water use, with a focus on the use of stable isotopes and remote sensing. These technological advances provide new tools that assist in addressing critical issues in dryland ecohydrology under climate change.
\end{abstract}

\section{Introduction}

Drylands are regions with relatively low precipitation, long dry spells (e.g., dry seasons), and frequent occurrence of water scarce conditions. They are typically located in areas of prevalent divergence in the patterns of atmospheric circulation, on the lee side ("rain shadow") of mountain chains, in arid continental regions, or in the proximity of cold ocean surfaces. The drylands definition is often based on total annual precipitation being low relative to potential evapotranspiration (ET). To this end an aridity index (AI), defined as the ratio between precipitation and potential ET, is used to classify drylands as regions where the $\mathrm{AI}$ is smaller than 0.65 (e.g., sub-humid dryland, semi-arid dryland).

Drylands collectively cover about $40 \%$ of the terrestrial land surface (Table 1 ) and contribute approximately $40 \%$ of global net primary productivity (Grace et al., 2006). Vegetation dynamics exert a strong control on the water cycle in drylands, due in part to the tight coupling that exists between the water, energy, and biogeochemical budgets in these systems (Noy-Meir, 1973; Austin et al., 2004; Wang et al., 2009a; Tietjen et al., 2010). For example, in the Mojave desert of the southwest United States, elevated winter precipitation stimulated a rapid increase in vegetation productivity, 
Table 1. The classification, percentage of global land area and percentage of global population of each dryland type. Data are from United Nation's Millennium Ecosystem Assessment (2005) and Gilbert (2011).

\begin{tabular}{lrrr}
\hline Dryland Classification & Aridity Index (AI) & Global Land Area (\%) & Global Population (\%) \\
\hline Dry subhumid & $0.50<\mathrm{AI}<0.65$ & $9.9 \%$ & $15.3 \%$ \\
Semi-arid & $0.20<\mathrm{AI}<0.50$ & $17.7 \%$ & $14.4 \%$ \\
Arid & $0.05<\mathrm{AI}<0.20$ & $12.1 \%$ & $4.1 \%$ \\
Hyper-arid & $\mathrm{AI}<0.05$ & $7.5 \%$ & $1.7 \%$ \\
\hline
\end{tabular}

which in turn reduced soil water storage by half - compared to a paired unvegetated site - and precluded deep drainage below the root zone (Scanlon et al., 2005). A converse example would be the conversion of perennial vegetation to annual crops, which is typically associated with an increase in groundwater recharge, and - in some cases - the rise of shallow water tables and salt accumulation at the ground surface, as observed in many drylands around the world, including the case of south western Australia.

Besides the strong linkage between water, energy and biogeochemical fluxes, across-scale hydrological connectivity is another important feature of arid and semiarid landscapes. Hydrological connectivity is a system-level property that results from the linkages in the networks of water transport through ecosystems, by which feedbacks and other emergent system behavior may be generated (Miller et al., 2012). Because of the low hydraulic conductivity of dry soils, the subsurface connectivity of arid and semiarid landscapes is generally low when compared with their wet and subhumid counterparts (Grayson et al., 1997). The connectivity provided by surface waters is often intermittent or ephemeral and limited to wet periods or seasons when surface overland flow occurs and the stream network is active. Hydrological connectivity is not well characterized in most systems and the challenge of modeling hydrological connectivity lies in the poor understanding of cross-scale interdependencies of the processes controlling water fluxes from the soil to the plant and the atmosphere (e.g., Loik et al., 2004). Representing and synthesizing hydrological connectivity, from the point to the landscape scale, will require enhanced knowledge of connections among hydrologic conditions, climate, vegetation, soil processes, and landscape morphology. Recent efforts have been focusing on better characterizing hydrological connectivity. For example, Wang et al. (2012a) developed a conceptual framework for upscaling ecohydrological and biogeochemical processes from point to watershed scales using electrical circuit analogies and Thévenin's theorem, highlighting its utility to represent concomitant processes at both small and large spatial scales.

Water is fundamental for biological processes responsible for ecosystem function and food production, and for abiotic processes controlling the land-atmosphere interactions. Dryland ecohydrology describes the hydrologic mechanisms that underlie ecological patterns and processes in water- limited ecosystems (Rodriguez-Iturbe, 2000; D'Odorico et al., 2010a). Currently, drylands support more than 2 billion people and comprise both natural and managed ecosystems (MEA, 2005; Gilbert, 2011). Growing global populations are expected to increase the pressure on these ecosystems, thereby further exacerbating the already tight limitations imposed by water availability and food security. Thus, there is an urgent need for better management strategies to avoid the emergence of potential conflicts resulting from poor understanding of the underlying ecohydrological processes. With increasing anthropogenic influences on hydrological cycles, research in ecohydrology is moving towards more humandominated landscapes (Jackson et al., 2009). Future environmental and socio-economic changes, such as rising $\mathrm{CO}_{2}$ and temperature, changing rainfall patterns and even dietary shifts are likely to have profound impacts on dryland ecosystem dynamics. Many dryland savannas and mixed cropping systems have a combination of different plant physiognomies, including both $\mathrm{C}_{3}$ and $\mathrm{C}_{4}$ plants (Wang et al., 2009b, 2010a). Since $\mathrm{C}_{3}$ and $\mathrm{C}_{4}$ plants respond to $\mathrm{CO}_{2}$ enrichment and temperature increase differently (Morgan et al., 2011), the combination of plant physiognomy increases the complexity of managing and predicting dryland responses to future environmental changes.

Not unique to drylands, but equivalently important in arid and semiarid landscapes, scale and scaling is another important issue in understanding and predicting ecohydrological processes (Seyfried and Wilcox, 1995; Becker and Braun, 1999). Scale is perceived differently by different researchers and for different research purposes. From the perspective of a small lysimeter study, a catchment of the size of $1 \mathrm{~km}^{2}$ may be considered large and heterogeneous, whereas a several thousand $\mathrm{km}^{2}$ basin may be considered small and homogeneous for global simulations (Bergström and Graham, 1998). In reality, processes are often observed at short time scales and small spatial scales and predictions are made for long time scales and large spatial scales. To make this link, it is essential to understand how the nature of spatial variability affects hydrological response over a range of scales, how to link the small-scale and large-scale observations and where the uncertainty lies. Upscaling typically consists of two steps: distributing the small-scale parameter over the interested area and aggregating the spatial distribution of the parameter into one single value; downscaling, on the other 
hand, involves disaggregating and singling out (Blöschl and Sivapalan, 1995). Scaling can be conducted either in a deterministic or a stochastic framework and scaling methods depend on the characteristic of the interested parameters. Scale and scaling issues have been discussed comprehensively in other reviews and syntheses (Blöschl and Sivapalan, 1995) and it is still an active area for ecohydrological research (Wilcox et al., 2003; Wang et al., 2012a).

In this synthesis, we aim to use ecohydrological principles and published literature to identify current critical issues in dryland research. Specifically, we will focus on some emerging issues in dryland research, including the relation between agriculture and water use, dryland population growth, shrub encroachment, desertification and dryland development. This list may not be exhaustive, but it includes some of the most challenging, emerging issues in dryland ecohydrology. Some of these points have been widely discussed elsewhere, while others are yet to draw the attention they demand. We will also discuss some current technical advances and future challenges in the developments of new research tools, including remote sensing and stable isotope monitoring tools, which will assist in addressing these critical issues in dryland ecohydrology.

\section{Critical issues in drylands}

\subsection{Dryland population growth, water demands and dryland agriculture}

Global water resources are inherently related to and affected by population growth (Vörösmarty et al., 2000). Developing nations account for $90 \%$ of dryland populations. Figure 1 shows that a large proportion of dryland countries (i.e., countries in which the dryland area exceeds $50 \%$ of the total area, based on the definition provided in the Introduction) exhibit a much higher population growth compared with the global average.

Water footprint is an indicator of water consumption that includes both direct and indirect water use, and is defined as the total volume of freshwater used to produce the goods and services consumed by an individual or a community (Chapagain and Hoekstra, 2004; Liu and Savenije, 2008). Most of the human appropriation of freshwater resources is used for food production (e.g., Falkenmark and Rockström, 2004). Without accounting for any change in the per capita water footprint, the ongoing demographic growth is expected to increase the pressure exerted by humanity on the global water resources. At the same time, however, it has been reported that economic growth is allowing some populations to have access to more water intensive food commodities; the shift to more meat based diets will substantially increase the per capita water use, further increasing the water footprint of human societies (Liu et al., 2008; Strzepek and Boehlert, 2010). Changes in water consumption, induced by shifts to more

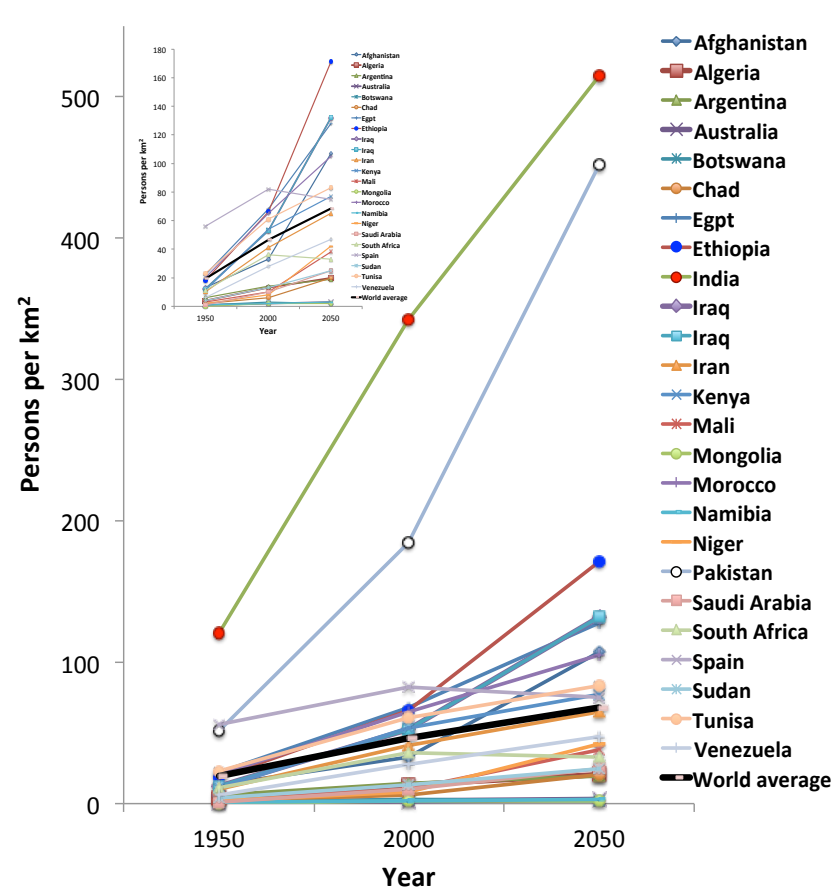

Fig. 1. Average global population density growth and population density growth for dryland dominated countries (defined as where dryland areas are larger than $50 \%$ of the total areas). The inset represents the same information but excludes India and Pakistan for better display of the other countries. The population data is from the Department of Economic and Social Affairs of the United Nations (2004). http://www.un.org/esa/population/ publications/longrange2/WorldPop2300final.pdf.

water intense diets, could be dramatic. For example, in China and India, the per capita water footprint is currently 1071 and $1089 \mathrm{~m}^{3} /$ person/year, respectively, while in the United States it is $2842 \mathrm{~m}^{3} /$ person/year (Hoekstra and Mekonnen, 2012). By 2050, the populations of China and India are predicted to reach 1.42 and 1.61 billion, respectively (the population data is from the State of World Population 2010). If in these countries the per capita water footprint reaches the levels of the United States (this may not be achievable in reality due to the size of the population and low per capita economic level in these countries), their freshwater consumption would become at least three times larger than the current rates. Since water resources are already under severe pressure in both countries, meeting this future demand will be a daunting challenge for the next generation.

Population growth in conjunction with an increase in per capita water use is affecting a number of dryland countries around the world. Food security is at risk when in these countries the available freshwater is not sufficient to produce the food needed by their populations. Severe water stress conditions are expected to cause malnourishment, famine, and social unrest. The United Nations Food and Agriculture Organization (FAO) predicts that by 2050 agriculture will have to support additional 2.7 billion people (FAO, 2006a). To feed 
the increasing global population while eradicating malnourishment, the human appropriation of freshwater resources needs to double within the next 40-50 yr (Falkenmark and Rockström, 2004). Our ability to meet such demand is constrained by the limited availability of accessible freshwater resources on Earth. From the water perspective, an increase in food production can - in principle - be achieved by (1) increasing irrigated land, (2) expanding croplands at the expenses of natural ecosystems, and (3) developing new technologies that enhance the water use efficiency of agricultural production ("more crop per drop") through genetically modified crops or water saving agricultural techniques. However, theses options are not without constraints. In terms of the first option, currently, $19 \%$ of the global agricultural land is irrigated and produces $40 \%$ of the world's food supply (Hanjra and Qureshi, 2010). Meeting the projected food demand solely by expanding irrigated areas is unfeasible (Falkenmark and Rockström, 2004). Irrigation requires water withdrawal from lakes, streams or groundwater. Globally, about $2600 \mathrm{~km}^{3}$ of water are already withdrawn every year for irrigation (Strzepek and Boehlert, 2010). Agriculture accounts for more than $66 \%$ of the total human withdrawals. Most of the rivers flowing through dryland regions are already intensively exploited. Many of them (e.g., the Rio Grande or the Colorado River) barely make it to the ocean. An expansion of irrigation can contribute only in part to the projected increase in food demand.

In terms of expanding croplands, there are only limited opportunities to increase agricultural production by sustainably increasing the arable land and the global agricultural area is not expected to substantially increase (Fedoroff et al., 2010). However, drylands are often considered as possible candidates for cropland expansion (both for food and biofuel production). For example, in 2009, the World Bank identified 600 million hectares of African savannas and woodlands as the primary expansion opportunity to increase food production in Africa (World Bank, 2009). However, the conversion to agriculture of these drylands would not occur at no cost if we account for the environmental services they currently provide, including rangeland, firewood production, carbon sequestration, maintenance of biodiversity, and provision of habitat for wildlife. Moreover, the conversion of a grassland-dominated system to cropland has the potential to reduce runoff dramatically (Twine et al., 2004) with important impact on stream and fluvial habitats. One of the challenges in dryland ecohydrology is the disconnection of research focusing on upland processes and studies on stream biology. When some of the methods developed in humid regions are applied to drylands, some distinctive ecohydrological features of dryland streams need to be accounted for. For instance, biotic indices (e.g., invertebrate taxa richness) can be used as indicators of stream health and land use impacts (Lenat and Crawford, 1994) and to characterize terrestrialaquatic interactions in drylands, but characteristics that are uniquely associated with drylands (e.g., ephemeral streams) need to be considered and further explored.

Regardless of a possible increase in arable area, dryland agriculture is expected to be particularly vulnerable to the effect of climate and land use change. The effect of climate change on crop production is of considerable concern. Predictions for the US central Great Plains indicate that the negative effects of rising temperature on crop production will offset the positive impacts of $\mathrm{CO}_{2}$ increase (Ko et al., 2012). The effects of climate change are already being felt in the global food markets, and are becoming particularly strong in some dryland areas, where crops fail and yields decline (FAO, 2006a). In the semiarid tropics, smallholder farmers rely on extremely variable and uncertain rainfall regimes. The vulnerability is also contributed by soil salinization and other forms of human- or climate-induced land and water degradation. Future climate projections in drylands are uncertain but indicate a possible increase in climate variability, a decrease in mean precipitation (Sheffield and Wood, 2007), the occurrence of more frequent droughts, and increased temperature extremes (Schlenker and Lobell, 2010). All of these factors will further exacerbate the vulnerability of agricultural production in the dry tropics. For instance, in the near future (20-30 yr) climate change is predicted to threaten food security in southern Africa (Lobell et al., 2008) and the Sahel (Patricola and Cook, 2010), while in other areas (e.g., central Africa), the uncertainty of these estimates is too large to make informed decisions. In addition to changes in mean climate conditions, changes in climate variability pose further challenges on farmers who may be able to adapt to long-term changes but not to increases in interannual variability.

Furthermore, the response to climate change in drylands not only depends on climate itself, but also on the social and economic aspects of the society. For example, in pastoral societies, changes in rainfall amount and arrival time will change vegetation productivity. However, to translate productivity consequences into livelihood and development impacts requires additional levels of cross-disciplinary synthesis to incorporate geographical, social, economic, and technological dimensions of the linked human-ecohydrology system. In agricultural systems, we can also see the amplification of meteorological impact by anthropogenic activities. For example, recent work (e.g., Mwale, 2003; Falkenmark and Rockström, 2008) has begun to show that in many cases agricultural drought can be quite substantial (i.e., complete crop failure), even when meteorological drought (i.e., rainfall deficit) is mild. Therefore, the frequency and severity of a "drought year" depends heavily on both social and agricultural factors, which are themselves strongly coupled to spatial expressions of hydrological dynamics, land cover patterns, and local coping behaviors. Although much progress has been made in understanding changes in food security under the threat of climate change (Hanjra and Qureshi, 2010), it is still unclear how an intensification of climate fluctuations 
might affect food production and what policies could mediate those impacts.

It has been noted that, despite water scarcity some societies are meeting their food demand through the importation of food commodities. International trade of food products has been associated with a virtual transfer of the water required for their production (Allan, 1998). Virtual water trade is, however, only a short term remedy: it does not correct the imbalance existing between the growing global population and the limited available water resources; it does not promote equality in the access to freshwater (Seekell et al., 2011); it reduces societal resilience (D'Odorico et al., 2010b), and makes some societies (e.g., China) increasingly dependent on water resources that they do not control (Carr et al., 2012).

\subsection{Dryland development challenges}

By taking a broader view of drylands not just as ecosystems, but as coupled human-environment systems, we can see the pivotal importance of ecohydrology in the pursuit of human development. In developing countries, the livelihoods and well-being of rural dryland populations tend to be tightly and directly linked to ecological processes, as societies in these regions typically engage in household-scale, low-technology livestock and/or crop production (Reynolds et al., 2007). Pastoral systems use natural dryland ecosystems extensively for livestock production, with mobility, flexibility, and common pool resource management institutions to track and access shifting resource availability (Robinson et al., 2011). Dryland smallholder agriculture is typically rain-fed, or may utilize localized sources or on-site catchment for limited irrigation, making crop yields highly dependent on seasonal rainfall and farming practices that affect the partitioning of precipitation in the water balance equation (Falkenmark and Rockström, 2008; Notenbaert et al., 2009).

Today, both systems, and hybrids thereof, are struggling to support human livelihoods and maintain resilient ecological processes in the face of growing populations, land use pressures, and climate change. African drylands, which cover $40 \%$ of the continent's land area, epitomize these challenges for poverty reduction, economic development and environmental sustainability. Poverty itself limits choices for coping strategies, such as technological investments or adoption of industrial or other livelihoods (Thornton et al., 2006). A human-ecohydrology lens can be applied to help understand how ecohydrologic conditions govern rural productivity, and can point to appropriate, creative approaches to forge more beneficial feedbacks between landscapes and livelihoods.

In pastoral systems, land degradation is part of a "diminishing resource syndrome", in which increased livestock densities and limited mobility feed back to degrade the capacity of landscapes to capture and convert incoming rainfall into primary production, while competing land uses and conversion of higher productivity rangelands to agriculture reduce the area available for livestock production. Rangeland rehabilitation research has shown that in many cases physical manipulations such as microcatchments can reinstate more productive water-soil-plant relations. But additional, more holistic assessments are needed to determine: (a) the extent to which livelihood benefits from land rehabilitation can mitigate other stressors due to demographic and land use pressures, and (b) the optimal location of rehabilitation efforts in heterogeneous landscapes to generate the greatest impacts on productivity and livelihoods.

Many smallholder dryland cropping systems in Africa have also undergone suites of social and ecohydrological changes. Demographic pressures have led to increased farming intensity, reduced fallow periods, and driven cropping into increasingly marginal areas. Crop genetics, fertilizers, and pest management have spurred the Green Revolution in agricultural intensification in Asia and Latin America, but not in rural Africa. Lack of water availability and irrigation infrastructure are key barriers to such development (Rockström et al., 2007). While major aid organizations are currently redoubling their efforts to create more efficient, drought resistant crops for Africa, knowledge of dryland ecohydrology has inspired other approaches: Conservation Agriculture and the Green Water approach (FAO, 2006b; Falkenmark and Rockström, 2008). With the mantra, "more crop per drop," these approaches seek to maximize the fraction of precipitation (or irrigation) that is routed through productive plant growth (transpiration), by reducing losses to runoff, evaporation, and deep drainage. With technologically simple tactics like microcatchments, mulching, and strategic timing of watering, crop yields per water input can increase severalfold (FAO, 2006b; Falkenmark and Rockström, 2008). At present, we lack coupled evaluations of plant-level (crop genetics) and farm-level (conservation agriculture) approaches, which assess the climatic, ecological, and social conditions under which these approaches offer higher or more sustainable productivity gains.

\subsection{Desertification and human vs. climate induced desertification}

Many drylands around the world are affected by rapid change in vegetation cover and composition, hydrologic conditions, and soil properties, which result in an overall loss of ecosystem services and poses serious threats to sustainable livelihoods. The process underlying these changes is often termed "desertification" (D'Odorico et al., 2012). The United Nations Convention to Combat Desertification (UNCCD) (1994) defines desertification as land degradation in arid, semi-arid or sub-humid areas resulting from various factors that include climate variations and human activities. About $10 \%$ to $20 \%$ of global drylands suffer from desertification and are prone to a decline in land productivity (Reynolds et al., 2007; D'Odorico et al., 2012). A number of processes can contribute to this decline, including soil 
erosion (Li et al., 2007; Ravi et al., 2009), salinization, loss of soil fertility or depletion of seed banks. These factors have important impacts on vegetation density and species composition. Desertification is commonly associated with changes that persist for several decades and are presumably irreversible, at least within the time scales of a few human generations.

As recognized by the UNCCD (1994), dryland desertification may be broadly associated with two underlying drivers, namely changes in climate or human activities. These drivers may cause an ecosystem shift to a "desertified" state, while positive feedbacks stabilize the system in this new state (D'Odorico et al., 2012). To effectively combat degradation, we need to quantitatively assess the extent to which a region's degradation is caused by climate variations or human activities. Recent methods utilizing remote sensing and modeling techniques to distinguish between human versus climate induced desertification are presented in detail in the "technical advances" section.

\subsection{Ecohydrological consequences of shrub encroachment}

Woody plant encroachment is the increase in the density and cover of woody plants into open grasslands and woodlands, and is a global phenomenon (Archer et al., 1995; Eldridge et al., 2011). Encroachment is associated with a number of ecosystem changes ranging from a change in the spatial distribution of soil nutrients, altered habitat value for wildlife, and changes in the ability of the soil to redistribute water vertically and horizontally (Schlesinger et al., 1990; Archer et al., 2001; Bhark and Small, 2003; Zarovalli et al., 2007). Changes in shrubland communities that alter the balance between precipitation, run-off, interception and infiltration are likely to have marked effects on the structure and function of shrubland ecosystems. The likely long-term effect is to reinforce the persistence of shrublands at the expense of grasslands (Reynolds et al., 2007).

Although water is a substantial driver of ecosystem processes in semi-arid shrublands, relatively little is known about run-off and infiltration processes and the hydrological responses to encroachment. The dichotomy between shrub canopy and interspace is a major determinant of ecosystem productivity and diversity. The heterogeneous nature of the vegetation in drylands is thought to be controlled by processes of upslope water erosion and sedimentation, and complex interactions among individual plants and the surrounding soil matrix (Puigdefébregas and Sanchez, 1996; Bochet et al., 1999; Reid et al., 1999; Wang et al., 2007; Ravi et al., 2008). Both the movement and storage of water within shrublands is highly variable (e.g., Breshears et al., 2009). These issues make it extremely difficult to model or predict likely hydrological responses to changes in management or climate.

\subsubsection{The effects at plot scale}

A number of knowledge gaps relate to the effect of woody encroachment on soil hydrologic conditions in semi-arid systems, which hinder the prediction of climate change effects on soil-vegetation interactions. Below we identify the main knowledge gaps that relate to shrub encroachment, with an emphasis on eastern Australia and the western United States:

1. Enhanced levels of infiltration surrounding the canopy are a defining feature of arid zone shrub communities (e.g., Bhark and Small, 2003). Soil porosity is greater and macropores are present adjacent to the roots and stem of woody plants, which also have well-developed tap roots allowing the plants to access water from greater depths (Archer et al., 2002). While the extent of infiltration is known to decline with increasing distance from the canopy, the exact nature of this decline is largely unknown for most woody species, and has been studied in only a few arid zone shrubs (e.g., Atriplex spp., Dunkerley, 2000). Climate change predictions show that the total precipitation amount will generally decrease in drylands (Solomon et al., 2007) with a concurrent increase in storm amounts (Ohmura and Wild, 2002). The intensified storms have been shown to increase soil water holding by deeper infiltration. This soil water is less susceptible to evaporation, thus the increased storm intensity may increase the water availability for shrub/tree dominated microsites (Raz-Yaseef et al., 2012), but this depends on soil texture and rainfall intensity and needs further investigation for other areas.

2. The relative interception value of woody plants is poorly known (e.g., Savenije, 2004; Gerrits et al., 2007). For example, we are aware of only a few studies of interception of shrubs (e.g., Wood and Wood, 1986) and there are few data on interception and stemflow for woody plants in arid and semi-arid eastern Australia. Limited data suggest that stemflow and interception for box eucalypt communities are low ( $<3 \%$ of total rainfall) (Johns, 1981; Tunstall and Connor, 1981), suggesting that the majority of precipitation passes directly through the canopies. Thus, while this suggests that surface hydrological conditions are more influenced by soil characteristics than plant architecture, there are limited studies to confirm this.

3. The degree to which woody and encroached communities increase water erosion (either through physical effects or by reducing infiltration) is poorly understood (Eldridge et al., 2003). Hydrological models have been used to study how the amount of rainfall reaching the ground, and hence the risk of erosion, varies according to changing cover of woody plant canopies (Wu et al., 2001). As woody vegetation tends to intercept more rainfall than understory vegetation (Thurow, 1991; Wu 
et al., 2001), it could be argued that woody vegetation reduces the risk of erosion to a greater degree. However, the situation is far more complex. As raindrops falling from taller ( $>2 \mathrm{~m}$ tall) canopies tend to be more erosive (i.e., with higher kinetic energy) than those falling from shorter heights (Moss and Green, 1978), canopy height is likely to be an important driver of erosion risk. There is an urgent need to test empirically some of the relationships between canopy cover and height for different vegetation communities.

4. The relationship between woody plants and understory herbaceous cover is complex, and likely mediated by grazing intensity (Barger et al., 2011). While overgrazing is likely to lead to reductions in ground cover, this may be compensated for by increases in the cover of other components such as litter. The interception capacity of grasses is biomass- and cover-dependent (Crouse et al., 1966), ranging from 0.3 to $2.5 \mathrm{~mm}$ of water (Branson et al., 1972). However, litter also has the capacity to intercept rainfall, depending on the type and depth (Branson et al., 1972). Litter cover, origin and degree of incorporation are known to be correlated with the capacity of the soil to resist erosion and infiltrate water (Tongway, 1995). However, the relationships among litter depth, type and interception are not known.

5. Many studies have shown higher nutrient levels (e.g., Charley and West, 1975; Schlesinger et al., 1996; Ravi et al., 2009; Wang et al., 2009b) and higher soil carbon concentrations (e.g., Wang et al., 2009c) under the shrub/tree areas compared with open areas. In fact, woody plant encroachments affect both soil moisture and soil biogeochemical processes through physical (e.g., shading effect to decrease evaporation) and biotic factors (e.g., water uptake through deep rooting); furthermore, soil moisture itself strongly control soil biogeochemical cycles in water-limited systems (e.g., Austin et al., 2004; Wang et al., 2009a). How to separate the woody plant and soil moisture effects on soil biogeochemical cycles is important to better understand the dynamic differences between under canopy and open canopy areas, and the tree-grass interactions. This information is also important to upscale the plot-scale observations to larger scales.

6. Runoff coefficients are thought to be much less in woody communities than in the herbaceous communities that they replace. For example, run-off coefficients reported by Harrington et al. (1981) for the semiarid Australian woodlands were seven-times lower for thickets of trees and shrubs than for the inter-thickets, similar to results from the piñon-juniper woodlands in the western United States (Reid et al., 1999). Data on the differences in runoff coefficients across soil types and vegetation communities are needed in order to param- eterize runoff and erosion models for wooded communities. More importantly, there is limited understanding in terms of the runoff coefficient change for the same woody encroachment areas but under different precipitation regimes.

7. There is a pressing need to separate out the direct effects of woody plants on sub-surface flow, through enhancement of macro-porosity, from the indirect effect of woody plants via their mediation of soil surface condition. Increased shading under woody plants is known to alter the richness and cover of understory plants (Smit et al., 2007). Sub-canopy microsites are also highly preferred by biocrusts; complex communities of mosses, lichens and cyanobacteria (Eldridge et al., 2010). Biocrusts are known to have substantial effects on hydrology in the near-surface layers (Eldridge et al., 2010), but the extent to which this is moderated by shrubs, or by the herbivores that tend to graze under the canopy, is largely unknown. New models of water flow through soils, using different supply potentials, are currently being evaluated using systems-based approaches (e.g., Eldridge et al., 2010).

\subsubsection{The effects on regional hydrological processes}

Shrub encroachment may also have dramatic effects on regional hydrological processes. Encroachment can lead to land-to-atmosphere feedbacks with possible impacts on rainfall and temperature regimes. Small and Kurc (2003) found only limited potential feedbacks to precipitation in Creosote bush (Larrea tridentata) shrublands in North America. However, it has been argued that reduced woody cover may reduce rainfall by altering surface roughness, ET and cloud formation (McAlpine et al., 2009). Much of this is largely unknown, however, and the exact magnitude of any regional hydrological changes resulting from encroachment can only be speculated upon. Shrub encroachment can affect the land surface albedo, emissivity, and roughness with important impacts on the near surface climate (Beltran-Przekurat et al., 2008). Even though in some cases changes in albedo are negligible, the increase in soil energy storage at encroached area can modify the microclimate with a positive feedback on vegetation (D'Odorico et al., 2010c; He et al., 2010). Recent regional climate modeling activities that seek to change the boundary conditions of the surface state may provide some insight into the influence and strength of land-atmosphere couplings as a response to changing surface conditions.

These effects are likely to change markedly with increases in global temperatures, increases in the severity of high intensity rainfall events, and greater spatial variability in groundcover and therefore the capacity of the soil to resist erosion. The replacement of grassland by shrubland exposes more of the surface to the action of raindrop impact resulting in accelerated erosion and potential sedimentation (Abrahams et al., 1994). These regional studies reinforce the notion that more 
catchment-specific data are needed for both the ecological (e.g., tree rooting depth, canopy architecture and structure, depth of water intake) and hydrological (soil texture and hydraulic conductivity, soil moisture availability, hydrological connectivity) components of these systems, in order to improve our catchment wide modeling of the likely ecohydrological effects of vegetation change.

The positive effects of woody plants on soils and understory vegetation needs to be balanced with their negative effects of competing directly for water and intercepting rainfall. Whilst the relationship between woody plants, understory plants and soil water is poorly understood, and the degree to which one is offset by the other often depends on the scale at which these effects are measured. Given the close links between woody vegetation and water flow in these patterned landscapes, removal of woody vegetation is likely to have drastic impacts for the capture and utilization of water at a landscape scale, but may increase short-term productivity at a local scale. The situation is analogous to other patterned landscapes worldwide where removal of vegetation results in a reduced efficiency of water and nutrient capture in the landscape and therefore reduced overall function and productivity (Tongway et al., 2001). The impact of woody plant encroachment on runoff and streamflow conditions has been typically associated with a reduction in base flow (Chang, 2002) though some recent studies are showing that the opposite might also happen (Wilcox and Huang, 2010).

\section{Technical advances addressing dryland issues}

As already noted, the variability and distribution of water availability in the landscape is of paramount importance for drylands. There are a number of exciting developments in monitoring tools useful for ecohydrological research over the last decade. For example, field deployable laser based spectroscopy approaches that determine the ratios of hydrogen and oxygen isotopes (Lee et al., 2005; Wang et al., 2009d, 2012b), cosmic-ray (Zreda et al., 2008) and electromagnetic imaging (i.e., EMI) based plot to watershed scale in-situ soil moisture monitoring, development of distributedtemperature sensing (DTS), and remote sensing based estimates of key hydrological variables such as soil moisture, ET and water level (Alsdorf et al., 2000) are revolutionizing the scales and precision of information sources to inform ecohydrological measurement and investigation. The modeling and conceptual advances in soil moisture (Rodriguez-Iturbe et al., 1999; Guswa et al., 2002), scale and scaling (Blöschl and Sivapalan, 1995; Rodriguez-Iturbe et al., 1995; Wilcox et al., 2003) also enhance our understanding of dryland ecohydrolocial processes. It is impractical to exhaust all the advances and here we select remote sensing and stable isotopes as examples and discuss three areas in details. First we discuss recent methodology advances to differentiate human vs. climate induced desertification using remote sensing product and time series analysis, corresponding to the critical issue (2.3); the second and third parts focus on using remote sensing and stable isotope based techniques to better characterize the water budget at various scales, which apply to all the critical issues. Remote sensing has the advantage in temporal and spatial duration and stable isotopes have the advantage in detecting mechanisms.

\subsection{Detecting human vs. climate induced desertification}

Differentiating human vs. climate induced desertification is a challenging task. Techniques to quantify the relative influence of each cause have been developed to identify regions where land management options are likely to be most effective in stopping and remediating this degradation. One of the earliest attempts to explicitly do this can be found in Evans and Geerken (2004). In their methodology the first step was to establish a relationship between inter-annual variations in vegetation and precipitation. The satellite based Normalized Difference Vegetation Index (NDVI) was used as a proxy for vegetation. Evans and Geerken (2004) provide a generic way of identifying the best linear correlation between the precipitation, accumulated over some period, and the annual maximum NDVI. This extends the work of many others who have also investigated the relationship between the NDVI and climatic variables (Hielkema et al., 1986; Yang et al., 1997; du Plessis, 1999; Schmidt and Karnieli, 2000; Wang et al., 2001). By removing this identified climate contribution from the NDVI time series the influence of the climate variability is removed, and any remaining trend in these residuals is then ascribed to human activities (Fig. 2). This method is hereafter referred to as RESTREND. Using this methodology Evans and Geerken (2004) identified the regions undergoing significant human caused degradation in the Syrian drylands, which account for a large portion of the total degraded areas.

The RESTREND method has subsequently been used in many studies to identify the contribution of climate variability and human activities to land degradation (Herrmann et al., 2005; Wessels et al., 2007; Propastin and Kappas, 2008; Paudel and Andersen, 2010; Brinkmann et al., 2011). Some studies have further shown the connection between the identified degraded areas and a particular human activity such as over-grazing (Geerken and Ilaiwi, 2004; Paudel and Andersen, 2010).

The RESTREND method has proven to be robust and effective in many studies. The RESTREND method is however, relatively simple and it contains several limitations. It assumes there is a linear relationship between vegetation and precipitation; that the identified relationship is not overly influenced by the presence of degradation; and that the vegetation measure (e.g., NDVI) can represent all forms of degradation of interest. Each of these limitations has been addressed in various studies. The assumption of a linear relationship between vegetation (NDVI) and precipitation appears robust within dryland systems, however the assumption breaks 


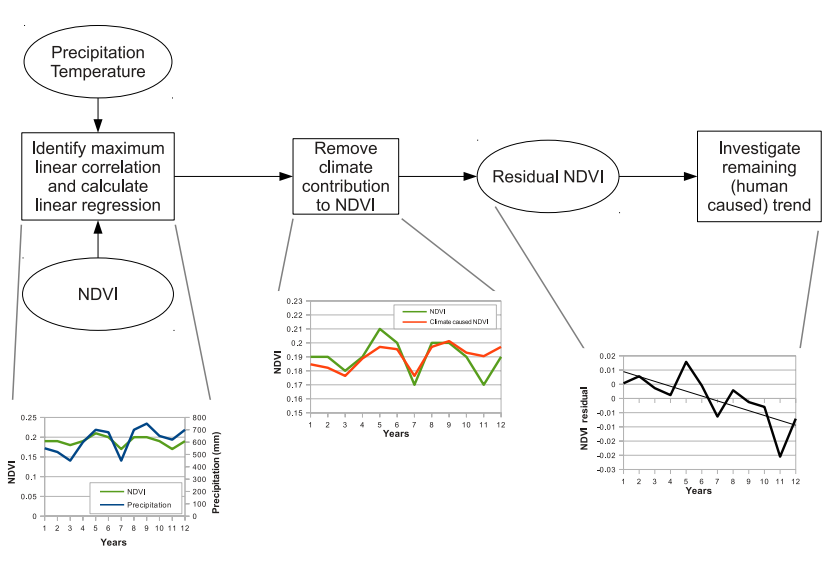

Fig. 2. Flowchart of RESTREND method to differentiate human vs. climate induced desertification. First, climate (precipitation, temperature) and vegetation (NDVI) time series are used to find the climate averaging window that produces the highest correlation. Using this window, the linear regression is calculated. Then, this regression equation is used to calculate the climate caused NDVI component. The difference between the observed NDVI and the climate caused NDVI is the NDVI residual. The trend in this residual indicates the human caused changes in the vegetation.

down in wetter environments. Wessels et al. (2007) applied a log transform to the precipitation data to account for the lower responsiveness of vegetation to precipitation in high precipitation areas. With this change they found that the RESTREND method was successful in identifying the degrading regions across a large climatic gradient in South Africa. Others found similar non-linear relationships between vegetation and precipitation when applied outside the drylands (e.g., Paudel and Andersen, 2010).

The RESTREND method assumes that the relationship seen in the observations between the vegetation (NDVI) and precipitation contains the climate influence, while the residuals of this relationship contain all other influences on the vegetation. However, if an area has been degraded during the observation record this will be evident as a smaller vegetation response to the same precipitation input, and the identified vegetation-precipitation relationship will embody some of this response. That is, the RESTREND method necessarily underestimates the degradation (or improvement) that has occurred. This limitation has been addressed by estimating the "potential" vegetation given the climate conditions. This potential vegetation has been estimated in a number of ways. Wessels et al. (2008) used the 90th percentile of net primary production (NPP) for each biophysical land unit to define the potential production of the land. Xu et al. (2010) used NPP calculated using the Carnegie-AmesStanford Approach (CASA) model to determine the potential of an area, while Zhang et al. (2011) used this approach with estimates from the Thornthwaite Memorial and Synthetic models as well.
In drylands degradation may occur without any discernible change in the vegetation measure, usually NDVI. Probably the most important of these changes is caused by overgrazing. The livestock will preferentially graze on the most palatable species which can result in the replacement of these species by less palatable species. Such a change in vegetation composition may not produce any change in the observed NDVI but may dramatically reduce the livestock carrying capacity of the land. It has been proposed that by utilizing the phenological cycle as embodied in time series of remotely sensed vegetation indices, such as NDVI, it is possible to differentiate vegetation species. Most conventional studies only use particular phenologically relevant variables such as green period, peaking time, or onset/end of green period (e.g., Boyd et al., 2011). Others have used decision (regression) tree techniques based on a collection of the above variables (Hansen et al., 2000; Bradley and Mustard, 2008). These approaches do not make full use of the information available over the entire phenological cycle. One technique used to extract information from the full time series is to treat the multi-temporal data set as if it is a multi-spectral data set and apply spectral-unmixing algorithms to it (Singh and Glenn, 2009), another is to decompose the shape of the phenological cycle using Fourier transforms and base the classification on the Fourier components, which is the approach used in Geerken et al. (2005) and Evans and Geerken (2006). Geerken et al. (2005) presents the Fourier Filtered Cycle Similarity algorithm in which the user identifies optimum weightings for Fourier harmonics calculated from a reference vegetation cycle. These optimum parameters are applied to the entire area of interest and pixels of similar shape to the reference cycle are deemed to be the same vegetation type. The measurement of similarity is based on a linear regression between the reference cycle and the target cycle. To overcome the high computational burden and subjective nature of this algorithm, Evans and Geerken (2006) introduced the Fourier component based shape similarity measure. This similarity measure is based directly on the Fourier Components and is designed mathematically such that it is invariant to modifications unrelated to the plants phenology, that is, the similarity measure is invariant to vertical displacements caused by different backgrounds (soils), temporal shifts caused by changes in the onset of the wet season or across strong climate gradients, and magnitude variations, which can be caused by changes in the coverage or vigour of the vegetation. These techniques have been further developed by Geerken (2009). They have been found to provide accurate vegetation type classifications down to the level of differentiating shrub types. Geerken (2009) also introduced a change detection algorithm that differentiates between coverage changes and vegetation type changes making these shape similarity based approaches very promising as a means to detect early stages of degradation in drylands such as the replacement of palatable shrubs by unpalatable ones. 
To date, attempts to differentiate between human-induced and climate caused degradation have focused on precipitation as representing the required climate variations. However, in cold dryland regions where temperatures reach below zero celcius, temperature changes may also play an important role. Liu et al. (2012) apply the RESTREND method to the Mongolian Steppe and found that inter-annual changes in temperature had a significant impact on the vegetation and so must be included along with precipitation in order to account for the full climate effect. As global warming continues, it is likely that the long-term change in temperature will play a larger role in many environments and should not be neglected. Liu et al. (2012) found that once the climatic effects had been removed, regions of degradation in the Mongolian Steppe could largely be attributed to over-grazing due to the increase in Cashmere goat population. The challenge now is to determine what actions can be taken to stop, or even reverse, the degradation without damaging one of Mongolia's largest export markets and before the degradation becomes irreversible.

\subsection{Remote sensing of water budget components in drylands}

Remote sensing provides the capacity to bridge the point scale focus of many ecohydrological investigations to the larger spatial extents required for whole system assessment. One of the key advantages of remote sensing platforms is the availability of data to allow extrapolation not just in space, but also across the temporal domain, offering insight into pattern change and development through time. Recent advances in hydrological remote sensing (Lettenmaier and Famiglietti, 2006) have seen research efforts that seek to address the outstanding problem of observation based hydrological closure (Sheffield et al., 2009). Such efforts to quantify the fluxes and stores of water within the terrestrial system have relevance to better understanding the hydrological implications of climate change and also the coupling and feedback mechanisms that directly impact upon ecohydrology studies.

Of considerable interest in large scale ecohydrological applications are hydrological related variables associated with the estimation of soil moisture, precipitation, vegetation and water stress, and the linked process of ET.

\subsubsection{Soil moisture}

Soil moisture sensing from space has been employed for a variety of applications in the hydrological sciences, most regularly in updating the state parameter for land surface modeling applications (Pauwels et al., 2001; Pan et al., 2008). From an ecohydrological perspective, characterizing the antecedent condition of a system along with the mean, range and variability of soil moisture dynamics within it, are of primary interest. Both active and passive sensor microwave based systems are available for remote estimation of soil moisture, with each representing a compromise between spatial and temporal resolution. Microwave based soil moisture retrieval is limited by the depth of measurement (on the order of just a few centimetres). As such, sensors only have the capability to inform upon the near surface soil moisture, although techniques to extrapolate through the soil column are used (Hoeben and Troch, 2000). Although routine daily global scale estimation of soil moisture is possible, making them ideal for large scale studies, a clear limitation of passive microwave sensing is the coarse resolution of retrievals (McCabe et al., 2005). While active radar systems provide a higher spatial resolution (up to a few kilometres), the repeat time is generally on the order of a few days. Passive systems on the other hand can provide sub-daily retrievals, but with a coarser spatial coverage (approximately $25 \mathrm{~km}$ ). Efforts to merge data sets from multiple systems and sensors have the potential to offer improved insight for large scale ecohydrological investigations (Liu et al., 2011a).

From an in-situ monitoring perspective, perhaps the most important recent advance in soil moisture estimation is the development of the COSMOS monitoring system (Zreda et al., 2008). Based on the release of both fast and slow neutrons from interactions between water in the soil column and a regular flux of cosmic rays from space, the COSMOS system provides for the first time, a typical model resolution (100's of meters) estimate of the soil wetness in a system. In addition, the hydrogen in the top layer will have more sensitivity to the neutron counts, thus COSMOS has the potential to discriminate soil moisture at the topsoil and soil moisture in the subsoil, if combined with modeling to separate the various hydrogen pools in the average measurement. The COSMOS installations represent a revolution in terms of bridging the spatial divide that often exists between remote sensing and in-situ measurement approaches. Efforts to develop a distributed network of these systems globally will see an improved capacity to monitor ecosystem change and development in ways not previously available.

\subsubsection{Precipitation}

Spatial and temporal maps of rainfall distribution provide key constraints on the health and development of ecohydrological systems. While there is a wide range of satellite based retrievals that can provide enhanced characterization of ecosystem condition or state, a number of these space based platforms provide multi-decadal sequences of important terrestrial variables. Remote measurement of precipitation has an extensive history, with numerous hydrological investigations being informed by the two decades long Tropical Rainfall and Measurement Mission (TRMM) satellite system (Kummerow et al., 2000) and other related sensors.

Using both microwave based passive and active radar systems, together with infrared based sensors on board geostationary platforms, researchers have been able to provide improved spatial and temporal detail on precipitation structure 


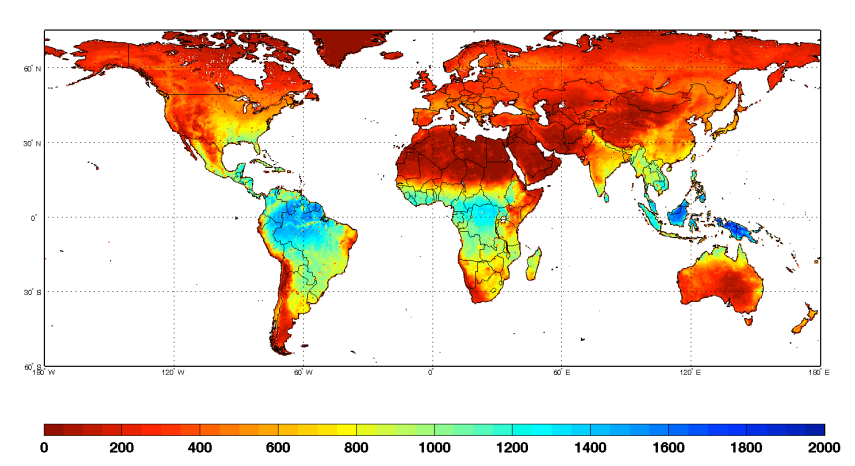

Fig. 3. Map of global evapotranspiration (in $\mathrm{mm}$ ) distribution for the year 2006. Data are from Global Land-surface Evaporation: Amsterdam Method (GLEAM).

and pattern. Over the coming years, the next generation of satellite rainfall systems, referred to as the Global Precipitation Mission (GPM), will provide a much needed update to the space based rainfall monitoring capacity. With GPM, the spatial and temporal resolution of rainfall retrievals will eclipse previous incarnations, and offer the needed level of detail to enable a range of hydrological and ecohydrological investigations.

\subsubsection{Evapotranspiration}

Together with precipitation, ET represents the major water flux exchanges occurring within the Earth system. Encompassing water loss from open water, bare soil and canopy components $(E)$ and plant water release through the process of transpiration $(T)$, the two terms can routinely exceed $90 \%$ of the water lost from dryland ecosystems. For this reason, considerable effort has been directed at developing approaches for its accurate estimation at a range of spatial and temporal scales (McCabe and Wood, 2006). Indeed, for dryland systems, a compromise between the spatial resolution of measurements and the temporal frequency is often required, given the rapid rate at which water is exchanged through the system.

Numerous techniques for flux estimation exist, with the recent review by Kalma et al. (2008) providing a good overview of these different approaches. While many satellite based algorithms rely on the use of surface temperature and air temperature gradients to gauge heat flux potential, the surface temperature itself is a useful proxy for surface condition and stress: particularly if the diurnal temperature range can be retrieved (Sobrino and El Kharraz, 1999; Stisen et al., 2008).

Recent efforts towards better understanding the global distribution of fluxes and variability in flux retrieval approaches has been undertaken under the auspices of the Global Energy and Water Cycle Experiment (GEWEX) Landflux project (Jimenez, 2011; Mueller et al., 2011). Landflux is an effort to provide the community with a climatological record of

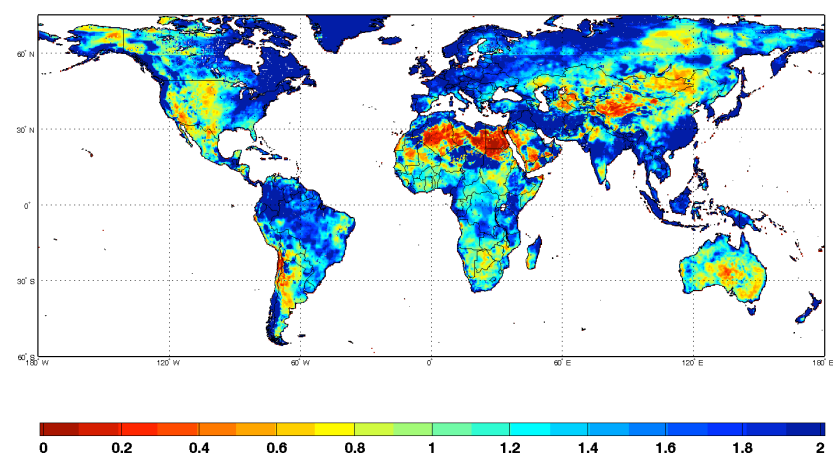

Fig. 4. Map of aridity index for the year 2006, using Global Precipitation Climatology Centre (GPCC) descriptions of rainfall at $0.5 \times 0.5$ degree and the Global Land-surface Evaporation: Amsterdam Method (GLEAM) for evapotranspiration. Note that evapotranspiration rather than potential evapotranspiration values were used in calculating the aridity index for this map.

land surface heat fluxes that can be used not only for global climate model evaluation, but also more process and system scale modeling and interpretation activities. Most importantly, it will seek to be consistent with a suite of other climate system product data sets, reducing the risk of introduced bias as a response to independent forcing data sets.

These data have considerable utility in describing the longterm variability and range of ecosystem behavior around the globe, allowing intercomparison of climate regions (arid, semi-arid, humid) with reduced bias as a result of data consistency. Also, other GEWEX data streams such as radiation, precipitation and ultimately soil moisture will allow further ecosystem analysis to be undertaken in a consistent framework, reducing one of the large uncertainties in mass and energy flux assessments (McCabe et al., 2008), the inherent variability in forcing data and subsequent response on model simulations.

Figure 3 illustrates a recent example of a multi-satellite Global Land- surface Evapotranspiration (GLEAM) product, developed by the Vrije University of Amsterdam (Miralles et al., 2011). The approach, along with a number of other global ET data sets (see Jimenez et al., 2011 for further details), allow for the calculation of simple ecosystem and catchment indices, such as the aridity index ( $P$ /potential ET) or evaporative fraction, providing a baseline characterization of ecohydrological response across spatial and temporal domains (see Fig. 4 for an example of such an index). Such data sets provide a much needed source of information on global patterns of evaporative response, and will prove useful in establishing change and trend detection in the hydrological cycle.

\subsubsection{Vegetation and water stress}

In addition to standard maps of land use and land cover which provide insight into the (often slowly) changing nature of the terrestrial surface (e.g., Domingues et al., 2007), there 
are a wide range of vegetation based indices that present details on the state and condition of vegetation across the globe. The range of available data can also include information on plant phenology, density and distribution (McVicar and Jupp, 1998; Badeck et al., 2004; White et al., 2009; Simard et al., 2011). Through integration with microwave, optical or infrared remote sensing data, the capacity to link the sub-surface land condition with the state and health of the overlying vegetation can be realized. While often empirical in nature, relationships between vegetation stress and remote sensing indices are commonly used in model and observation based studies - the most well recognized of these being the NDVI. Recent efforts to produce a data set of vegetation biomass from microwave based systems has a range of useful implication for understanding the shifting responses of ecohydrological systems. Unlike optical or infrared sensors, microwave remote sensing measures the total water content of the vegetation and soil continuum. Differentiating the strength of signal between these two land surface components provides the potential to describe the total above ground biomass. More importantly, using temporal sequences of these satellite systems provides a capacity to map large-scale changes of biomass response in ways that traditional indices such as NDVI are incapable of capturing (Jones et al., 2011; Liu et al., 2011b).

A number of remote sensing derived drought indices that are generally independent of vegetation state and rely more on meteorological or hydrological indicators, have also been produced (Sheffield and Wood, 2008). These existing and emerging data sets provide a near real-time capacity to understand the dynamic vegetation response to rapidly changing terrestrial conditions. Whether as a consequence of hydrological or other larger scale forcing to the system, such data - in combination with other remote sensing based retrievals - also allow a capacity to examine system recovery or ecosystem shift as a response to external drivers across local, regional and global scales.

\subsection{Evapotranspiration partition}

As noted above, ET is a major term in the water budget and accounts for up to $95 \%$ of water input (e.g., precipitation) in drylands (Huxman et al., 2005). At the same time, ET has two distinct components ( $E$ and $T$ ), which are controlled by different mechanisms. Partitioning ET is important not only for better understanding the water budget but also in predicting the biogeochemical fluxes driven by hydrological variations (e.g., Wang et al., 2010b; Raz-Yaseef et al., 2012). To efficiently use the limited water resources in drylands, we need to maximize the productive water loss $(T)$ and minimize the unproductive water loss $(E)$ (Wang and D'Odorico, 2008). Separating $E$ and $T$, however, has always been a difficult task, especially from the observational point of view at larger scales (see modeling exercise in Liu, 2009).
Stable isotopes of water provide a useful tool to separate $E$ and $T$, as $E$ and $T$ carry distinct isotopic signatures. Historically water isotopes have been widely used in hydrology to track the water movement and phase changes (Gat, 1996). The water stable isotopic compositions are traditionally measured by the isotope ratio mass spectrometry (IRMS), while the vapor phase measurements are usually based on cryogenic water vapor collection coupled with the IRMS method. Such methods are labor intensive and time consuming, as ${ }^{18} \mathrm{O}$ measurements require offline $\mathrm{CO}_{2}-\mathrm{H}_{2} \mathrm{O}$ equilibrium. The typical vapor equilibrium takes about $24 \mathrm{~h}$. Over the past decade, a revolutionary change in water isotope measurements has seen the appearance of spectroscopy based isotope instruments capable of making continuous measurements of water vapor isotopic compositions. This new type of instruments does not usually require pretreatment and have precisions similar to traditional cryogenic based mass spectrometry methods (Lee et al., 2005; Wen et al., 2008; Wang et al., 2009d; Griffis et al., 2010). Recent research has indicated that plant derived volatile compound induced spectral contamination in leaf and stem water measurements could affect the accuracy of water stable isotopic compositions significantly (West et al., 2010; Zhao et al., 2011), limiting the application of spectroscopy-based method to plant sample measurements. There are studies which developed post correction method for modest spectral contamination of plant tissues (Schultz et al., 2011), but this remains a topic requiring further developments. Nevertheless, the continuous measurement of water vapor isotope compositions allows for the direct quantification of the water vapor and will expand the capabilities of using stable isotopes for echohydrological research.

To assess ET partitioning using stable isotopes, three isotopic end members need to be quantified: the isotopic composition of ET $\left(\delta_{\mathrm{ET}}\right), T\left(\delta_{T}\right)$ and $E\left(\delta_{E}\right)$. Recent efforts have focused on developing, refining and assessing estimation methods of all three end members. $\delta_{\mathrm{ET}}$ is typically measured using the Keeling plot approach coupled with traditional cryogenic methods (e.g., Yepez et al., 2005). With the development of the new laser technique, Wang et al. (2012c) extended this technique to direct chamber measurements coupled with laser instruments. Good et al. (2012) quantified and compared the uncertainties using different $\delta_{\mathrm{ET}}$ estimation methods at tower scale and showed that the eddy covariance method has the largest uncertainties, while the Keeling plot and flux gradient methods have smaller and similar uncertainties.

$\delta_{E}$ is typically calculated by the Craig-Gordon model (Craig and Gordon, 1965), which describes $\delta_{E}$ as a function of humidity, kinetic and equilibrium isotope fractionation, the isotopic composition of water of the evaporation surface, and atmospheric vapor. Soderberg et al. (2012) showed that the traditional Craig-Gordon model could be improved by adding water potential terms for dry soils. 


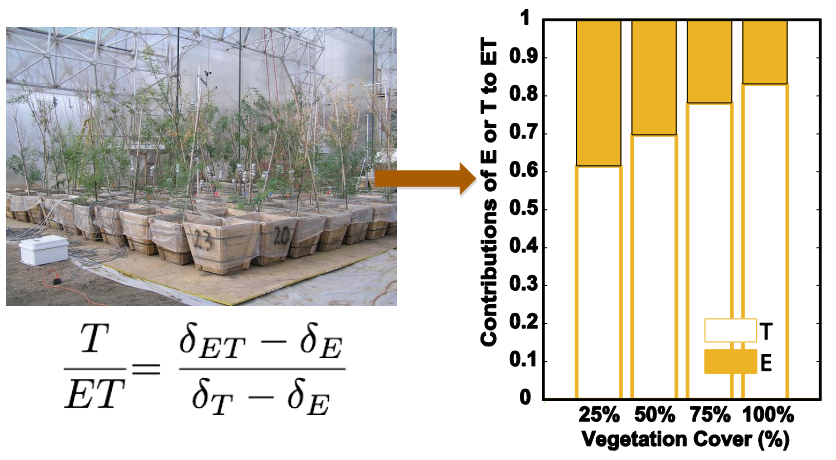

Fig. 5. An example of using laser-based stable isotope monitoring techniques to partition evapotranspiration. The left panel showed the experimental setup inside Biosphere 2 as well as the mass balance equation to calculate the evapotranspiration partition, and the right panel showed the increased transpiration/evapotranspiration ratio as vegetation cover increases, which was modified from Wang et al. (2010b).

Typically, $\delta_{T}$ is assessed indirectly using stem water measurements or leaf water measurements with leaf enrichment corrections. The use of stem water measurements is based on the assumption that leaves operate under isotopic steady state, so that $\delta_{T}$ is equal to the isotopic composition of plant source water. The assumption that leaves are in isotopic steady state is generally valid during midday because the magnitude of $T$ relative to the volume of leaf water is large and there is a rapid turnover of water in transpiring leaves. However, non-steady state isotopic enrichment is also common in many natural systems, especially during the early morning and late afternoon (e.g., Lai et al., 2005), when $T$ fluxes are lower. Taking advantage of the new laser technique, Wang et al. (2010b) reported the first direct measurements of $\delta_{T}$ using a customized leaf chamber and off-axis integrated cavity output spectroscopy water vapor isotope analyzer with pure nitrogen as purging gas. This method, however, has two limitations: (1) the limited availability of ultrapurity nitrogen gas makes this method unsuitable for many field applications; (2) the water-free and $\mathrm{CO}_{2}$-free inline environment affects stomata openings since humidity and $\mathrm{CO}_{2}$ have opposite effects on stomata openings, which may alter instantaneous $\delta_{T}$ values. Building on this configuration, Wang et al. (2012b) developed a new framework to remove the need for dry air by employing a mass balance approach for both isotopes and water vapor inside the leaf chamber. This direct and continuous $\delta_{T}$ quantification method has been shown to effectively capture the fast $\delta_{T}$ responses to radiation variations (Wang et al., 2012b).

Figure 5 presents an example of using laser-based isotope monitoring technique to partition ET inside Biosphere 2 and assess the $T / E T$ ratio changes with increasing vegetation cover (Wang et al., 2010b). With these new developments on the estimation of isotope end members, stable water isotopes provide a promising tool for partitioning ET across a range of spatial scales, which will significantly enhance water budget estimation in drylands.

\section{Summary and concluding remarks}

In this synthesis, based on hydrological principles and published literature, we highlight current critical issues in drylands ecohydrology ranging from societal aspects such as rapid population growth and the resulting food and water security implications, development issues, to natural aspects such as ecohydrological consequences of bush encroachment and differentiation of human versus climate induced desertification. We identify a number of research priorities to better address knowledge gaps. It should be noted that while some of the issues identified are not necessarily unique to drylands themselves (e.g., food and water security), the level of severity and urgency is certainly higher in drylands and deserves focused attention.

To improve current understanding and inform upon the needed research efforts to address these critical issues, we identify some recent technical advances in terms of monitoring dryland water dynamics, water budget and vegetation water use, with a focus on the use of stable isotopes and remote sensing. Stable isotopes have proven to be a powerful tool in tracing hydrological processes and vegetation water sources. Recent developments in spectroscopy have revolutionized the temporal and spatial resolution of isotopic monitoring, providing foundations to use isotope-based techniques to partition ET and characterize large-scale vegetation water use. Similarly, rapid developments in remote sensing based hydrological monitoring provide unprecedented temporal and spatial coverage in estimates of soil moisture, ET, water level and other important ecohydrological aspects of the system. For example, both active and passive microwave based systems are available for remote estimation of soil moisture, with each representing a compromise between spatial and temporal resolution. Combing microwave-based passive and active systems with infrared-based sensors allows for the spatial and temporal resolution of precipitation structure and pattern to be significantly improved. In addition, the capacity to monitor vegetation structure and vegetation health provides additional benefits for ecohydrological monitoring using remote sensing.

Due to inherent length limitations, there are a number of related technical advances in in-situ measurements, such as field portable 3D LIDAR systems for plant canopy analysis, distributed temperature sensors (DTS) for soil heat flux and connected water measurements, and electromagnetic imaging (EMI) and cosmic ray soil moisture observing systems (COSMOS) for soil moisture that were not covered in detail. Further information of such advances can be found in a number of synthesis papers devoted to some of these techniques (e.g., Robinson et al., 2008; Zreda et al., 2012). 
Overall, the analysis techniques, observation systems and monitoring advances discussed herein can all help to address some of the key ecohydrological issues of water and food security, consequences of bush encroachment and differentiation of human versus climate induced desertification. Inevitably, development issues in drylands require a hydrological, ecological and socio-economic understanding of the dryland ecosystem. An effective management of dryland systems demands that advances in monitoring, together with informative techniques for data analysis, should be linked within an interdisciplinary interpretive framework. Only then will the capacity to address the myriad issues facing dryland systems in the coming years be realized.

Acknowledgements. Lixin Wang acknowledges the financial support from Vice-Chancellor's postdoctoral research fellowship of University of New South Wales. We thank Chris Zou, Andrew Guswa, Naama Raz-Yaseef, Junguo Liu and one anonymous reviewer for their constructive comments.

Edited by: J. Liu

\section{References}

Abrahams, A. D., Parsons, A. J., and Wainwright, J.: Resistance to overland flow on semiarid grassland and shrubland hillslopes, Walnut Gulch, southern Arizona., J. Hydrol., 156, 431-446, 1994.

Allan, J. A.: Virtual Water: A Strategic Resource Global Solutions to Regional Deficits, Ground Water, 36, 545-546, doi:10.1111/j.1745-6584.1998.tb02825.x, 1998.

Alsdorf, D. E., Melack, J. M., Dunne, T., Mertes, L. A. K., Hess, L. L., and Smith, L. C.: Interferometric radar measurements of water level changes on the Amazon flood plain, Nature, 404, 174177, 2000.

Archer, N., Quinton, J., and Hess, T.: Below-ground relationships of soil texture, roots and hydraulic conductivity in two-phase mosaic vegetation in South-east Spain., J. Arid Environ., 52, 535553, 2002.

Archer, S., Schimel, D., and Holland, E.: Mechanisms of shrubland expansion: landuse, climate or $\mathrm{CO}_{2}$ ?, Climatic Change, 29, 9199, 1995.

Archer, S., Boutton, T. W., and Hibbard, K. A.: Trees in grasslands: biogeochemical consequences of woody plant expansion, in: Global Biogeochemical Cycles in the Climate Systems, edited by: Schulze, E. D., Heimann, M., Harrison, S., Holland, E., Lloyd, J., Prentice, C., and Schimel, D., Academic Press, San Diego, California, 115-130, 2001.

Austin, A. T., Yahdjian, L., Stark, J. M., Belnap, J., Porporato, A., Norton, U., Ravetta, D. A., and Schaeffer, S. M.: Water pulses and biogeochemical cycles in arid and semiarid ecosystems, Oecologia, 141, 221-235, 2004.

Badeck, F. W., Bondeau, A., Bottcher, K., Doktor, D., Lucht, W., Schaber, J., and Sitch, S.: Responses of spring phenology to climate change, New Phytologist, 162, 295-309, 2004.

Barger, N. N., Archer, S. R., Campbell, J. L., Huang, C. y., Morton, J. A., and Knapp, A. K.: Woody plant prolifera- tion in North American drylands: A synthesis of impacts on ecosystem carbon balance, J. Geophys. Res., 116, G00K07, doi:10.1029/2010JG001506, 2011.

Becker, A. and Braun, P.: Disaggregation, aggregation and spatial scaling in hydrological modelling, J. Hydrol., 217, 239-252, doi:10.1016/s0022-1694(98)00291-1, 1999.

Beltran-Przekurat, A., Pielke, R., Peters, D., Snyder, K., and Rango, A.: Modeling the effects of historical vegetation change on nearsurface atmosphere in the northern Chihuahuan Desert, J. Arid Environ., 72, 1897-1910, doi:10.1016/j.jaridenv.2008.05.012, 2008.

Bergström, S. and Graham, L. P.: On the scale problem in hydrological modelling, J. Hydrol., 211, 253-265, doi:10.1016/s00221694(98)00248-0, 1998.

Bhark, E. and Small, E.: Association between plant canopies and the spatial patterns of infiltration in shrubland and grassland of the Chihuahuan Desert, New Mexico, Ecosystems, 6, 185-196, 2003.

Blöschl, G. and Sivapalan, M.: Scale issues in hydrological modelling: A review, Hydrol. Process., 9, 251-290, doi:10.1002/hyp.3360090305, 1995.

Bochet, E., Rubio, J. L., and Poesen, J.: Modified topsoil islands within patchy Mediterranean vegetation in SE Spain, Catena, 38, 23-44, 1999.

Boyd, D., Almond, S., Dash, J., Curran, P., and Hill, R.: Phenology of vegetation in southern england from envisat meris terrestrial chlorophyll index (MTCI) data, Int. J. Remote Sens., 32, 84218447, doi:10.1080/01431161.2010.542194, 2011.

Bradley, B. and Mustard, J.: Comparison of phenology trends by land cover class: a case study in the Great Basin, USA, Global Change Biol., 14, 334-346, 2008.

Branson, F. A., Gifford, G. F., and Owen, J. R.: Rangeland Hydrology, Range Science, 1, Society for Range Management, Denver, Colorado, 1972.

Breshears, D. D., Whicker, J. J., Zou, C. B., Field, J. P., and Allen, C. D.: A conceptual framework for dryland aeolian sediment transport along the grassland-forest continuum: Effects of woody plant canopy cover and disturbance, Geomorphology, 105, 2838, 2009.

Brinkmann, K., Dickhoefer, U., Schlecht, E., and Buerkert, A.: Quantification of aboveground rangeland productivity and anthropogenic degradation on the Arabian Peninsula using Landsat imagery and field inventory data, Remote Sens. Environ., 115, 465-474, doi:10.1016/j.rse.2010.09.016, 2011.

Carr, J., D’Odorico, P., Laio, F., and Ridolfi, L.: On the temporal variability of the virtual water network, Geophys. Res. Lett., 39, L06404, doi:410.01029/02012GL051247, 2012.

Chang, M.: Forest Hydrology: an introduction to water and forests, CRC Press, 2002.

Chapagain, A. and Hoekstra, A.: Water footprints of nations Volume 1: Main Report, value of water research report series No. 16, UNESCO-IHE, Delft The Netherlands, 2004.

Charley, J. L. and West, N. E.: Plant-induced soil chemical patterns in some shrub-dominated semi-desert ecosystems of Utah, J. Ecol., 63, 945-963, 1975.

Craig, H. and Gordon, L. I.: Deuterium and oxygen-18 variations in the ocean and marine atmosphere, in: Proceedings of the conference on stable isotopes in oceanographic studies and paleotemperatures, edited by: Tongiorgi, E., Laboratory of Geology and 
Nuclear Science, Pisa, 9-130, 1965.

Crouse, R. P., Corbett, E. S., and Seegrist, D. W.: Methods of measuring and analysing rainfall interception by grass, International Association of Scientific Hydrologists Bulletin, 11, 110-120, 1966.

D’Odorico, P., Laio, F., Porporato, A., Ridolfi, L., Rinaldo, A., and Rodriguez-Iturbe, I.: Ecohydrology of terrestrial ecosystems, BioScience, 60, 898-907, 2010a.

D'Odorico, P., Laio, F., and Ridolfi, L.: Does globalization of water reduce societal resilience to drought?, Geophys. Res. Lett., 37, L13403, doi:410.11029/12010GL043167, 2010b.

D’Odorico, P., Fuentes, J. D., Pockman, W. T., Collins, S. L., He, Y., Medeiros, J. S., DeWekker, S., and Litvak, M. E.: Positive feedback between microclimate and shrub encroachment in the northern Chihuahuan desert, Ecosphere, 1, art17, doi:10.1890/ES1000073.1, 2010c.

D’Odorico, P., Bhattachan, A., Davis, K., Ravi, S., and Runyan, C.: Global desertification: drivers and feedbacks, Adv. Water Resour., doi:10.1016/j.advwatres.2012.01.013, 2012.

Domingues, T., Martinelli, L., and Ehleringer, J.: Ecophysiological traits of plant functional groups in forest and pasture ecosystems from eastern Amazonia, Brazil, Plant Ecol., 193, 101-112, doi:10.1007/s11258-006-9251-z, 2007.

du Plessis, W.: Linear regression relationships between NDVI, vegetation and rainfall in Etosha National Park, Namibia, J. Arid Environ., 42, 235-260, 1999.

Dunkerley, D. L.: Hydrological effects of dryland shrubs: defining the spatial extent of modified soil water uptake rates at an Australian desert site, J. Arid Environ., 45, 159-172, 2000.

Eldridge, D. J., Wilson, B. R., and Oliver, I.: Regrowth and soil erosion in the semi-arid woodlands of New South Wales, NSW Department of Land and Water Conservation, Sydney, 2003.

Eldridge, D. J., Bowker, M. A., Maestre, F. T., Alonso, P., Mau, R. L., Papadopoulos, J., and Escudero, A.: Interactive effects of three ecosystem engineers on infiltration in a semi-arid mediterranean grassland, Ecosystems, 13, 499-510, 2010.

Eldridge, D. J., Bowker, M. A., Maestre, F. T., Roger, E., Reynolds, J. F., and Whitford, W. G.: Impacts of shrub encroachment on ecosystem structure and functioning: towards a global synthesis, Ecol. Lett., 14, 709-722, doi:10.1111/j.14610248.2011.01630.x, 2011.

Evans, J. and Geerken, R.: Discrimination between climate and human-induced dryland degradation, J. Arid Environ., 57, 535554,2004

Evans, J. and Geerken, R.: Classifying rangeland vegetation type and coverage using a Fourier component based similarity measure, Remote Sens. Environ., 105, 1-8, 2006.

Falkenmark, M. and Rockström, J.: Balancing water for humans and nature : the new approach in ecohydrology, Earthscan Publications, London, 2004.

Falkenmark, M. and Rockström, J.: Building resilience to drought in desertification-prone savannas in Sub-Saharan Africa: The water perspective, Natural Resources Forum, 32, 93-102, 2008.

FAO: Food Security Statistics, Food and Agriculture Organization of the United Nations, Rome, Italy, 2006a.

FAO: Conservation Agriculture for SARD and Food Security in Southern and Eastern Africa (Kenya and Tanzania): Project Findings and Recommendations, Food and Agriculture Organziation, Rome, 2006b.
Fedoroff, N. V., Battisti, D. S., Beachy, R. N., Cooper, P. J. M., Fischhoff, D. A., Hodges, C. N., Knauf, V. C., Lobell, D., Mazur, B. J., Molden, D., Reynolds, M. P., Ronald, P. C., Rosegrant, M. W., Sanchez, P. A., Vonshak, A., and Zhu, J.-K.: Radically rethinking agriculture for the 21st century, Science, 327, 833834, doi:10.1126/science.1186834, 2010.

Gat, J.: Oxygen and hydrogen isotopes in the hydrologic cycle, Annu. Rev. Earth Pl. Sc., 24, 225-262, 1996.

Geerken, R.: An algorithm to classify and monitor seasonal variations in vegetation phenologies and their inter-annual change, ISPRS J. Photogramm., 64 422-431, 2009.

Geerken, R. and Ilaiwi, M.: Assessment of rangeland degradation and development of a strategy for rehabilitation, Remote Sens. Environ., 90, 490-504, 2004.

Geerken, R., Zaitchik, B., and Evans, J.: Classifying rangeland vegetation type and coverage from NDVI time series using Fourier Filtered Cycle Similarity, Int. J. Remote Sens., 26, 5535-5554, 2005.

Gerrits, A. M. J., Savenije, H. H. G., Hoffmann, L., and Pfister, L.: New technique to measure forest floor interception - an application in a beech forest in Luxembourg, Hydrol. Earth Syst. Sci., 11, 695-701, doi:10.5194/hess-11-695-2007, 2007.

Gilbert, N.: United Nations considers creating advisory panel on land degradation akin to IPCC, Nature, 477, 262-264, doi:10.1038/477262a, 2011.

Good, S., Soderberg, K., Wang, L., and Caylor, K.: Uncertainties in the assessment of the isotopic composition of surface fluxes: A direct comparison of techniques using laser-based water vapor isotope analyzers, Journal of Geophysical Research, 117, D15301, doi:10.1029/2011JD017168, 2012.

Grace, J., José, J. S., Meir, P., Miranda, H. S., and Montes, R. A.: Productivity and carbon fluxes of tropical savannas, J. Biogeogr. 33, 387-400, doi:10.1111/j.1365-2699.2005.01448.x, 2006.

Grayson, R., Western, A., Chiew, F., and Blöschl, G.: Preferred states in spatial soil moisture patterns: local and nonlocal controls, Water Resour. Res., 33, 2897-2908, 1997.

Griffis, T. J., Sargent, S. D., Lee, X., Baker, J. M., Greene, J., Erickson, M., Zhang, X., Billmark, K., Schultz, N., Xiao, W., and $\mathrm{Hu}, \mathrm{N}$. : Determining the oxygen isotope composition of evapotranspiration using eddy covariance, Bound.-Lay. Meteorol., 137, 307-326, doi:10.1007/s10546-010-9529-5, 2010.

Guswa, A. J., Celia, M. A., and Rodriguez-Iturbe, I.: Models of soil moisture dynamics in ecohydrology: A comparative study, Water Resour. Res., 38, 1166, doi:10.1029/2001wr000826, 2002.

Hanjra, M. and Qureshi, M.: Global water crisis and future food security in an era of climate change, Food Policy, 35, 365-377, 2010.

Hansen, M., DeFries, R., Townshend, J., and Sohlberg, R.: Global land cover classification at $1 \mathrm{~km}$ spatial resolution using a classification tree approach, Int. J. Remote Sens., 21, 1331-1364, 2000.

Harrington, G. N., Dawes, G. T., and Ludwig, J.: Vegetation patterns in a semi-arid eucalypt woodland in north-west NSW, Aust. J. Ecol., 6, 279-287, 1981.

He, Y., D’Odorico, P., Wekker, S. D., Fuentes, J., and Litvak, M.: On the impact of shrub encroachment on microclimate conditions in the northern Chihuahuan desert, J. Geophys. Res., 115, D21120, doi:10.1029/2009JD013529, 2010. 
Herrmann, S. M., Anyamba, A., and Tucker, C. J.: Recent trends in vegetation dynamics in the African Sahel and their relationship to climate, Global Environ. Change, 15, 394-404, 2005.

Hielkema, J., Prince, S., and Astle, W.: Rainfall and vegetation monitoring in the savanna zone of the democratic-republic of Sudan using the NOAA advanced very high-resolution radiometer, Int. J. Remote Sens., 7, 1499-1513, 1986.

Hoeben, R. and Troch, P. A.: Assimilation of active microwave observation data for soil moisture profile estimation, Water Resour. Res., 36, 2805-2819, 2000.

Hoekstra, A. Y. and Mekonnen, M. M.: The water footprint of humanity, Proc. Natl. Acad. Sci., 109, 3232-3237, doi:10.1073/pnas.1109936109, 2012.

Huxman, T., Wilcox, B., Breshears, D. D., Scott, R. L., Snyder, K. A., Small, E. E., Hultine, K., Pittermann, J., and Jackson, R.: Ecohydrological implications of woody plant encroachment, Ecology, 86, 308-319, doi:10.1890/03-0583, 2005.

Jackson, R. B., Jobbágy, E. G., and Nosetto, M. D.: Ecohydrology in a human-dominated landscape, Ecohydrology, 2, 383389, doi:10.1002/eco.81, 2009.

Jimenez, C.: Global inter-comparison of selected 1993-1995 monthly averaged land surface heat fluxes, J. Geophys. Res., 116, Cited By (since 1996) 1 Export Date 4 August 2011, 2011.

Johns, G. G.: Hydrological processes and herbage production in shrub invaded poplar box (Eucalyptus populnea) woodlands, Australian Rangeland Journal, 3, 45-55, 1981.

Jones, M. O., Jones, L. A., Kimball, J. S., and McDonald, K. C.: Satellite passive microwave remote sensing for monitoring global land surface phenology, Remote Sens. Environ., 115, 1102-1114, 2011.

Kalma, J. D., McVicar, T. R., and McCabe, M. F.: Estimating land surface evaporation: A review of methods using remotely sensed surface temperature data, Surveys in Geophysics, 29, 421-469, Cited By (since 1996) 53 Export Date 4 August 2011, 2008.

Ko, J., Ahuja, L. R., Saseendran, S. A., Green, T. R., Ma, L., Nielsen, D. C., and Walthall, C. L.: Climate change impacts on dryland cropping systems in the Central Great Plains, USA, Climatic Change, 111, 445-472, 2012.

Kummerow, C., Simpson, J., Thiele, O., Barnes, J., Chang, A. T. C., Stocker, E., Adler, R. F., and Hou, A.: The status of the Tropical Rainfall Measuring Mission (TRMM) after two years in orbit, J. Appl. Meteorol., 39, 1965-1982, 2000.

Lai, C., Ehleringer, J., Bond, B., and Paw U, K.: Contributions of evaporation, isotopic non-steady state transpiration and atmospheric mixing on the delta ${ }^{18} \mathrm{O}$ of water vapour in Pacific Northwest coniferous forests, Plant Cell Environ., 29, 77-94, 2005.

Lee, X., Sargent, S., Smith, R., and Tanner, B.: In situ measurement of the water vapor ${ }^{18} \mathrm{O} /{ }^{16} \mathrm{O}$ isotope ratio for atmospheric and ecological applications, J. Atmos. Ocean. Technol., 22, 555-565, 2005.

Lenat, D. and Crawford, J. K.: Effects of land use on water quality and aquatic biota of three North Carolina Piedmont streams, Hydrobiologia, 294, 185-199, doi:10.1007/bf00021291, 1994.

Lettenmaier, D. P. and Famiglietti, J. S.: Hydrology: Water from on high, Nature, 444, 562-563, 2006.

Li, J., Okin, G., Alvarez, L., and Epstein, H.: Quantitative effects of vegetation cover on wind erosion and soil nutrient loss in a desert grassland of southern New Mexico, USA, Biogeochemistry, 85, 317-332, 2007.
Liu, J.: Consumptive water use in cropland and its partitioning: a high-resolution assessment, Science in China Series E: Technological Sciences, 52, 3309-3314, 2009.

Liu, J. and Savenije, H. H. G.: Food consumption patterns and their effect on water requirement in China, Hydrol. Earth Syst. Sci., 12, 887-898, doi:10.5194/hess-12-887-2008, 2008.

Liu, J., Yang, H., and Savenije, H. H. G.: China's move to higherdiet hits water security, Nature, 454, 397, 2008.

Liu, Y., Evans, J. P., McCabe, M. F., Jeu, R. A. M. d., Dijk, A. I. J. M. v., Dolman, A. J., and Saize, I.: Drying and overgrazing decimate Mongolia's steppe, in prep., 2012.

Liu, Y. Y., Parinussa, R. M., Dorigo, W. A., De Jeu, R. A. M., Wagner, W., van Dijk, A. I. J. M., McCabe, M. F., and Evans, J. P.: Developing an improved soil moisture dataset by blending passive and active microwave satellite-based retrievals, Hydrol. Earth Syst. Sci., 15, 425-436, doi:10.5194/hess-15-425-2011, 2011 a.

Liu, Y. Y., De Jeu, R. A. M., McCabe, M. F., Evans, J. P., and Van Dijk, A. I. J. M.: Global long-term passive microwave satellitebased retrievals of vegetation optical depth, Geophys. Res. Lett., 38, L18402, doi:10.1029/2011GL048684, 2011b.

Lobell, D. B., Burke, M. B., Tebaldi, C., Mastrandrea, M. D., Falcon, W. P., and Naylor, R. L.: Prioritizing climate change adaptation needs for food security in 2030, Science, 319, 607-610, 2008.

Loik, M., Breshears, D. D., Lauenroth, W., and Belnap, J.: A multiscale perspective of water pulses in dryland ecosystems: climatology and ecohydrology of the western USA, Oecologia, 141, 269-281, 10.1007/s00442-004-1570-y, 2004.

McAlpine, C., Syktusw, J., Ryan, J., Deo, R., McKeon, G., McGowan, H., and Phinn, S.: A continent under stress: interactions, feedbacks and risks associated with impact of modified land cover on Australia's climate, Global Change Biol., 15, 22062223, 2009.

McCabe, M. F. and Wood, E. F.: Scale influences on the remote estimation of evapotranspiration using multiple satellite sensors, Remote Sens. Environ., 105, 271-285, 2006.

McCabe, M. F., Gao, H., and Wood, E. F.: Evaluation of AMSRE-derived soil moisture retrievals using ground-based and PSR airborne data during SMEX02, J. Hydrometeorol., 6, 864-877, 2005.

McCabe, M. F., Wood, E. F., Wojcik, R., Pan, M., Sheffield, J., Gao, H., and Su, H.: Hydrological consistency using multi-sensor remote sensing data for water and energy cycle studies, Remote Sens. Environ., 112, 430-444, 2008.

McVicar, T. R. and Jupp, D. L. B.: The current and potential operational uses of remote sensing to aid decisions on drought exceptional circumstances in Australia: a review, Agr. Syst., 57, 399-468, doi:10.1016/s0308-521x(98)00026-2, 1998.

MEA: Ecosystems and human well-being: desertification synthesis, World Resources Institute, Washington, DC, 2005.

Miller, G., Cable, J., McDonald, A., Bond, B., Franz, T., Wang, L., Gou, S., Tyler, A., Zou, C., and Scott, R.: Understanding ecohydrological connectivity in savannas: a system dynamics modeling approach, Ecohydrology, 5, 200-220, 2012.

Miralles, D. G., De Jeu, R. A. M., Gash, J. H., Holmes, T. R. H., and Dolman, A. J.: Magnitude and variability of land evaporation and its components at the global scale, Hydrol. Earth Syst. Sci., 15, 967-981, doi:10.5194/hess-15-967-2011, 2011. 
Morgan, J. A., LeCain, D. R., Pendall, E., Blumenthal, D. M., Kimball, B. A., Carrillo, Y., Williams, D. G., Heisler-White, J., Dijkstra, F. A., and West, M.: $\mathrm{C}_{4}$ grasses prosper as carbon dioxide eliminates desiccation in warmed semi-arid grassland, Nature, 476, 202-205, 2011.

Moss, A. J. and Green, T. W.: Erosive effects of the large water drops (gravity drops). that fall from plants, Aust. J. Soil Res., 25, 9-20, 1978.

Mueller, B., Seneviratne, S. I., Jimenez, C., Corti, T., Hirschi, M., Balsamo, G., Ciais, P., Dirmeyer, P., Fisher, J. B., Guo, Z., Jung, M., Maignan, F., McCabe, M. F., Reichle, R., Reichstein, M., Rodell, M., Sheffield, J., Teuling, A. J., Wang, K., Wood, E. F., and Zhang, Y.: Evaluation of global observations-based evapotranspiration datasets and IPCC AR4 simulations, Geophys. Res. Lett., 38, L06402, doi:10.1029/2010GL046230, 2011.

Mwale, F. D.: Drought impact on maize production in Malawi, MS, International Institute for Infrastructural, Hydraulic and Environmental Engineering, Delft, The Netherlands, 2003.

Notenbaert, A., Herrero, M., Kruska, R. L., You, L., Wood, S., Thornton, P. E., and Omolo, A.: Classifying livestock production systems for targeting agricultural research and development in a rapidly changing world. ILRI Discussion Paper 19, ILRI (International Livestock Research Institute), Nairobi, 2009.

Noy-Meir, I.: Desert ecosystems: environment and producers, Annu. Rev. Ecol. Systemat., 4, 25-51, 1973.

Ohmura, A. and Wild, M.: Is the hydrological cycle accelerating?, Science, 298, 1345-1346, doi:10.1126/science.1078972, 2002.

Pan, M., Wood, E. F., Wojcik, R., and McCabe, M. F.: Estimation of regional terrestrial water cycle using multi-sensor remote sensing observations and data assimilation, Remote Sens. Environ., 112, 1282-1294, 2008.

Patricola, C. and Cook, K.: Northern African climate at the end of the 21st century: integrated application of regional and global climate models, Clim. Dynam., 35, 193-212, 2010.

Paudel, K. P. and Andersen, P.: Assessing rangeland degradation using multi temporal satellite images and grazing pressure surface model in Upper Mustang, Trans Himalaya, Nepal, Remote Sens. Environ., 114, 1845-1855, doi:10.1016/j.rse.2010.03.011, 2010.

Pauwels, V. R. N., Hoeben, R., Verhoest, N. E. C., and De Troch, F. P.: The importance of the spatial patterns of remotely sensed soil moisture in the improvement of discharge predictions for smallscale basins through data assimilation, J. Hydrol., 251, 88-102, 2001.

Propastin, P. and Kappas, M.: Reducing uncertainty in modeling the NDVI-precipitation relationship: a comparative study using global and local regression techniques, GIScience Remote Sens., 45, 47-67, doi:10.2747/1548-1603.45.1.47, 2008.

Puigdefébregas, J. and Sanchez, G.: Geomorphological implications of vegetation patchiness on semi-arid slopes. In Advances in Hillslope Processes, in: Advances in Hillslope Processes, edited by: Anderson, M. G. and Brooks, S. M., Wiley, Chichester, UK, 1027-1060, 1996.

Ravi, S., D’Odorico, P., Wang, L., and Collins, S. L.: Form and function of grass ring patterns in arid grasslands: the role of abiotic controls, Oecologia, 158, 545-555, 2008.

Ravi, S., D'Odorico, P., Wang, L., White, C. S., Okin, G. S., Macko, S. A., and Collins, S. L.: Post-fire resource redistribution in desert grasslands: a possible negative feedback on land degradation, Ecosystems, 12, 434-444, 2009.
Raz-Yaseef, N., Yakir, D., Schiller, G., and Cohen, S.: Dynamics of evapotranspiration partitioning in a semi-arid forest as affected by temporal rainfall patterns, Agr. Forest Meteorol., 157, 77-85, doi:10.1016/j.agrformet.2012.01.015, 2012.

Reid, K. D., Bradford, P. W., Breshears, D. O., and MacDonald, L.: Runoff and erosion in a piñon-juniper woodland: influence of vegetation patches, Soil Sci. Soc. Am. J., 63, 1869-1879, 1999.

Reynolds, J., Smith, D. S., Lambin, E., Turner, B., Mortimore, M., Batterbury, S., Downing, T., Dowlatabadi, H., Fernández, R., Herrick, J., Huber-Sannwald, E., Leemans, R., Lynam, T., Maestre, F., Ayarza, M., and Walker, B.: Global desertification: building a science for dryland development, Science, 316, 847851, 2007.

Robinson, D. A., Campbell, C. S., Hopmans, J. W., Hornbuckle, B. K., Jones, S. B., Knight, R., Ogden, F., Selker, J., and Wendroth, O.: Soil Moisture Measurement For Ecological And Hydrological Watershed-scale Observatories: A Review, Vadose Zone J., 7 , 358-389, doi:10.2136/vzj2007.0143, 2008.

Robinson, T., Thornton, P. E., Franceschini, G., Kruska, R. L., Chlozza, F., Notenbaert, A., Cecchi, G., Herrero, M., Epprecht, M., Fritz, S., You, L., Conchedda, G., and See, L.: Global livestock production systems, Food and Agriculture Organization of the United Nations (FAO) and International Livestock Research Institute (ILRI), Rome, 2011.

Rockström, J., Lannerstad, M., and Falkenmark, M.: Assessing the water challenge of a new green revolution in developing countries, Proceedings of the National Academy of Sciences of the United States of America, 104, 6253-6260, doi:10.1073/pnas.0605739104, 2007.

Rodriguez-Iturbe, I.: Ecohydrology: A hydrologic perspective of climate-soil-vegetation dynamics, Water Resour. Res., 36, 3-9, 2000.

Rodriguez-Iturbe, I., Vogel, G. K., Rigon, R., Entekhabi, D., Castelli, F., and Rinaldo, A.: On the spatial organization of soil moisture fields, Geophys. Res. Lett., 22, 2757-2760, 1995.

Rodriguez-Iturbe, I., D’Odorico, P., Porporato, A., and Ridolfi, L.: On the spatial and temporal links between vegetation, climate, and soil moisture, Water Resour. Res., 35, 3709-3722, 1999.

Savenije, H. H. G.: The importance of interception and why we should delete the term evapotranspiration from our vocabulary, Hydrol. Process., 18, 1507-1511, doi:10.1002/hyp.5563, 2004.

Scanlon, B. R., Levitt, D. G., Reedy, R. C., Keese, K. E., and Sully, M. J.: Ecological controls on water-cycle response to climate variability in deserts, Proc. Natl. Acad. Sci., 102, 6033-6038, doi:10.1073/pnas.0408571102, 2005.

Schlenker, W. and Lobell, D.: Robust negative impacts of climate change on African agriculture, Environ. Res. Lett., 5, 014010 doi:10.011088/011748-019326/014015/014011/014010, 2010.

Schlesinger, W. H., Reynolds, J. E., Cunningham, G. L., Huenneke, L. E., Jarrell, W. M., Virginia, R. A., and Whitford, W. G.: Biological feedbacks in global desertification, Science, 247, 10431048, 1990.

Schlesinger, W. H., Raikes, J. A., Hartley, A. E., and Cross, A. F.: On the spatial pattern of soil nutrients in desert ecosystems, Ecology, 77, 364-374, 1996.

Schmidt, H. and Karnieli, A.: Remote sensing of the seasonal variability of vegetation in a semi-arid environment, J. Arid Environ. 45, 43-59, 2000. 
Schultz, N. M., Griffis, T. J., Lee, X., and Baker, J. M.: Identification and correction of spectral contamination in ${ }^{2} \mathrm{H} /{ }^{1} \mathrm{H}$ and ${ }^{18} \mathrm{O} /{ }^{16} \mathrm{O}$ measured in leaf, stem, and soil water, Rapid Commun. Mass Sp., 25, 3360-3368, 2011.

Seekell, D., D'Odorico, P., and Pace, M.: Virtual water transfers unlikely to redress inequality in global water use, Environ. Res. Lett., 6, 024017, doi:10.1088/1748-9326/6/2/024017, 2011.

Seyfried, M. and Wilcox, B.: Scale and the nature of spatial variability: field examples having implications for hydrologic modeling, Water Resour. Res., 31, 173-184, 1995.

Sheffield, J. and Wood, E. F.: Characteristics of global and regional drought, 1950-2000: Analysis of soil moisture data from off-line simulation of the terrestrial hydrologic cycle, J. Geophys. Res., 112, D17115, doi:10.1029/2006JD008288, 2007.

Sheffield, J. and Wood, E. F.: Global trends and variability in soil moisture and drought characteristics, 1950-2000, from observation-driven simulations of the terrestrial hydrologic cycle, J. Climate, 21, 432-458, 2008.

Sheffield, J., Ferguson, C. R., Troy, T. J., Wood, E. F., and McCabe, M. F.: Closing the terrestrial water budget from satellite remote sensing, Geophys. Res. Lett., 36, L07403, doi:10.1029/2009GL037338, 2009.

Simard, M., Pinto, N., Fisher, J. B., and Baccini, A.: Mapping forest canopy height globally with spaceborne lidar, J. Geophys. Res. G: Biogeosciences, 116, G04021, doi:10.1029/2011JG001708, 2011.

Singh, N. and Glenn, N.: Multitemporal spectral analysis for cheatgrass (Bromus tectorum) classification, Int. J. Remote Sens., 30, 3441-3462, doi:10.1080/01431160802562222, 2009.

Small, E. and Kurc, S.: Tight coupling between soil moisture and the surface radiation budget in semiarid environments: Implications for land-atmosphere interactions, Water Resour. Res., 39, 1278, doi:10.1029/2002WR001297, 2003.

Smit, C., Vandenberghe, C., den Ouden, J., and Muller-Scharer, H.: Nurse plants, tree saplings and grazing pressure: changes in facilitation along a biotic environmental gradient, Oecologia, 152, 265-273, 2007.

Sobrino, J. A. and El Kharraz, M. H.: Combining afternoon and morning NOAA satellites for thermal inertia estimation 1. Algorithm and its testing with Hydrologic Atmospheric Pilot Experiment-Sahel data, J. Geophys. Res., 104, 9445-9453, 1999.

Soderberg, K., Good, S. P., Wang, L., and Caylor, K.: Stable isotopes of water vapor in the vadose zone: A review of measurement and modeling techniques, Vadose Zone J., in press, doi:10.2136/vzj2011.0165, 2012.

Solomon, S., Qin, D., Manning, M., Chen, Z., Marquis, M., Averyt, K., Tignor, M., and Miller, H.: IPCC, 2007: Climate Change 2007: The Physical Science Basis. Contribution of Working Group I to the Fourth Assessment Report of the Intergovernmental Panel on Climate Change, Cambridge University Press, Cambridge and New York, 996 pp., 2007.

Stisen, S., Sandholt, I., Nørgaard, A., Fensholt, R., and Jensen, K. H.: Combining the triangle method with thermal inertia to estimate regional evapotranspiration - Applied to MSG-SEVIRI data in the Senegal River basin, Remote Sens. Environ., 112, 1242-1255, 2008.

Strzepek, K. and Boehlert, B.: Competition for water for the food system, Philos. T. R. Soc. B, 365, 2927-2940, doi:10.1098/rstb.2010.0152, 2010.
Thornton, P. K., Jones, P. G., Owiyo, T., Kruska, R. L., Herrero, M., Kristjanson, P., Notenbaert, A., Bekele, N., and Omolo, A.: Mapping climate vulnerability and poverty in Africa: Report to the Department for International development, ILRI, Nairobi, 171 pp., 2006.

Thurow, T. L.: Hydrology and erosion, in: Grazing Management: an Ecological Perspective, edited by: Heitschmidt, R. K. and Stuth, J. W., Timber Press, Portland, Oregon, 1991.

Tietjen, B., Jeltsch, F., Zehe, E., Classen, N., Groengroeft, A., Schiffers, K., and Oldeland, J.: Effects of climate change on the coupled dynamics of water and vegetation in drylands, Ecohydrology, 3, 226-237, doi:10.1002/eco.70, 2010.

Tongway, D.: Monitoring soil productive potential, Environm. Monit. Assess., 37, 309-318, 1995.

Tongway, D. J., Valentin, C. J., and Seghieri, J.: Banded vegetation patterning in arid and semiarid environments: ecological processes and consequences for management, Springer-Verlag, New York, 2001.

Tunstall, B. R., and Connor, D. J.: Internal water balance of brigalow (Acacia harpophylla F. Muell.) under natural conditions, Aust. J. Plant Physiol., 2, 489-499, 1981.

Twine, T. E., Kucharik, C. J., and Foley, J. A.: Effects of land cover change on the energy and water balance of the Mississippi river basin, J. Hydrometeorol., 5, 640-655, 2004.

UNCCD: United Nations Convention to Combat Desertification, United Nations, Geneva, Switzerland, 58 pp., 1994.

Vörösmarty, C. J., Green, P., Salisbury, J., and Lammers, R. B.: Global Water Resources: Vulnerability from Climate Change and Population Growth, Science, 289, 284-288, doi:10.1126/science.289.5477.284, 2000.

Wang, J., Price, K., and Rich, P.: Spatial patterns of NDVI in response to precipitation and temperature in the central Great Plains, Int. J. Remote Sens., 22, 3827-3844, 2001.

Wang, L. and D'Odorico, P.: The limits of water pumps, Science, 321, 36-37, 2008.

Wang, L., D'Odorico, P., Ringrose, S., Coetzee, S., and Macko, S.: Biogeochemistry of Kalahari sands, J. Arid Environ., 71, 259279 doi:10.1016/j.jaridenv.2007.03.016, 2007.

Wang, L., D’Odorico, P., Manzoni, S., Porporato, A., and Macko, S.: Carbon and nitrogen dynamics in southern African savannas: the effect of vegetation-induced patch-scale heterogeneities and large scale rainfall gradients, Climatic Change, 94, 63-76, doi:10.1007/s10584-009-9548-8, 2009a.

Wang, L., D’Odorico, P., Okin, G., and Macko, S.: Isotope composition and anion chemistry of soil profiles along the Kalahari Transect, J. Arid Environ., 73, 480-486, doi:10.1016/j.jaridenv.2008.11.010, 2009b.

Wang, L., Okin, G. S., Caylor, K. K., and Macko, S. A.: Spatial heterogeneity and sources of soil carbon in southern African savannas, Geoderma, 149, 402-408, doi:10.1016/j.geoderma.2008.12.014, 2009c.

Wang, L., Caylor, K., and Dragoni, D.: On the calibration of continuous, high-precision $\delta^{18} \mathrm{O}$ and $\delta^{2} \mathrm{H}$ measurements using an off-axis integrated cavity output spectrometer, Rapid Commun. Mass Sp., 23, 530-536, doi:10.1002/rcm.3905, 2009d.

Wang, L., D’Odorico, P., Ries, L., and Macko, S.: Patterns and implications of plant-soil $\delta^{13} \mathrm{C}$ and $\delta^{15} \mathrm{~N}$ values in African savanna ecosystems, Quaternary Res., 73, 77-83, doi:10.1016/j.yqres.2008.11.004, 2010a. 
Wang, L., Caylor, K. K., Villegas, J. C., Barron-Gafford, G. A., Breshears, D. D., and Huxman, T. E.: Evapotranspiration partitioning with woody plant cover: assessment of a stable isotope technique, Geophys. Res. Lett., 37, L09401, doi:10.1029/2010GL043228, 2010b.

Wang, L., Zou, C., O’Donnell, F., Good, S., Franz, T., Milller, G., Caylor, K., Cable, J., and Bond, B.: Characterizing ecohydrological and biogeochemical connectivity across multiple scales: a new conceptual framework, Ecohydrology, 5, 221-233, doi:10.1002/eco.187, 2012a.

Wang, L., Good, S. P., Caylor, K. K., and Cernusak, L.: Direct quantification of leaf transpiration isotopic composition, Agricultural and Forest Meteorology, 154-155, 127-135, doi:10.1016/j.agrformet.2011.10.018, 2012b.

Wang, L., Niu, S., Good, S., Soderberg, K., Zhou, X., Xia, J., Sherry, R., Luo, Y., Caylor, K., and McCabe, M.: The effect of warming on grassland evapotranspiration partitioning using laser-based isotope monitoring techniques, Geochim. Cosmochim. Ac., in review, 2012c.

Wen, X., Sun, X., Zhang, S., Yu, G., Sargent, S., and Lee, X.: Continuous measurement of water vapor $\mathrm{D} / \mathrm{H}$ and ${ }^{18} \mathrm{O} /{ }^{16} \mathrm{O}$ isotope ratios in the atmosphere, J. Hydrol., 349, 489-500, 2008.

Wessels, K., Prince, S., Malherbe, J., Small, J., Frost, P., and Van Zyl, D.: Can human-induced land degradation be distinguished from the effects of rainfall variability? A case study in South Africa, J. Arid Environ., 68, 271-297, 2007.

Wessels, K. J., Prince, S. D., and Reshef, I.: Mapping land degradation by comparison of vegetation production to spatially derived estimates of potential production, J. Arid Environ., 72, 19401949, doi:10.1016/j.jaridenv.2008.05.011, 2008.

West, A. G., Goldsmith, G. R., Brooks, P. D., and Dawson, T. E.: Discrepancies between isotope ratio infrared spectroscopy and isotope ratio mass spectrometry for the stable isotope analysis of plant and soil waters, Rapid Commun. Mass Sp., 24, 1948-1954, doi:10.1002/rcm.4597, 2010.

White, M. A., de Beurs, K. M., Didan, K., Inouye, D. W., Richardson, A. D., Jensen, O. P., O’Keefe, J., Zhang, G., Nemani, R. R., van Leeuwen, W. J. D., Brown, J. F., de Wit, A., Schaepman, M., Lin, X., Dettinger, M., Bailey, A. S., Kimball, J., Schwartz, M. D., Baldocchi, D. D., Lee, J. T., and Lauenroth, W. K.: Intercomparison, interpretation, and assessment of spring phenology in North America estimated from remote sensing for 1982-2006, Global Change Biol., 15, 2335-2359, 2009.

Wilcox, B. and Huang, Y.: Woody plant encroachment paradox: Rivers rebound as degraded grasslands convert to woodlands, Geophys. Res. Lett., 37, 1-5, 2010.

Wilcox, B., Breshears, D., and Allen, C. D.: Ecohydrology of a resource-conserving semiarid woodland: effects of scale and disturbance, Ecol. Monogr., 73, 223-239, 2003.
Wood, J. C. and Wood, M. K.: Influence of pinyon juniper and sagebrush control on infiltration rates and runoff water quality in northern New Mexico, New Mexico Journal of Science, 28, 7-20, 1986.

World Bank: Awakening Africa's sleeping giant: prospects for commercial agriculture in the Guinea savannah zone and beyond, New York, 2009.

Wu, X. B., Redeker, E. J., and Thurow, T. L.: Vegetation and water yield dynamics in an Edwards Plateau watershed, J. Range Manage., 54, 98-105, 2001.

Xu, D. Y., Kang, X. W., Zhuang, D. F., and Pan, J. J.: Multiscale quantitative assessment of the relative roles of climate change and human activities in desertification, Äì A case study of the Ordos Plateau, China, J. Arid Environ., 74, 498-507, doi:10.1016/j.jaridenv.2009.09.030, 2010.

Yang, W., Yang, L., and Merchant, J. W.: An assessment of AVHRR/NDVI-ecoclimatological relations in Nebraska, USA, Int. J. Remote Sens., 18, 2161-2180, 1997.

Yepez, E. A., Huxman, T. E., Ignace, D. D., English, N. B., Weltzin, J. F., Castellanos, A. E., and Williams, D. G.: Dynamics of transpiration and evaporation following a moisture pulse in semiarid grassland: A chamber-based isotope method for partitioning flux components, Agr. Forest Meteorol., 132, 359-376, 2005.

Zarovalli, M. P., Yiakoulaki, M. D., and Papanastasis, V. P.: Effects of shrub encroachment on herbage production and nutritive value in semi-arid Mediterranean grasslands, Grass Forage Science, 62, 355-363, 2007

Zhang, C., Wang, X., Li, J., and Hua, T.: Roles of climate changes and human interventions in land degradation: a case study by net primary productivity analysis in China's Shiyanghe Basin, Environmental Earth Sciences, 64, 2183-2193, 2011.

Zhao, L., Xiao, H., Zhou, J., Wang, L., Cheng, G., Zhou, M., Yin, L., and McCabe, M. F.: Detailed assessment of isotope ratio infrared spectroscopy and isotope ratio mass spectrometry for the stable isotope analysis of plant and soil waters, Rapid Commun. Mass Sp., 25, 3071-3082, 2011.

Zreda, M., Desilets, D., Ferre, T. P. A., and Scott, R. L.: Measuring soil moisture content non-invasively at intermediate spatial scale using cosmic-ray neutrons, Geophys. Res. Lett., 35, L21402, doi:10.1029/2008GL035655, 2008.

Zreda, M., Shuttleworth, W. J., Zeng, X., Zweck, C., Desilets, D., Franz, T., Rosolem, R., and Ferre, T. P. A.: COSMOS: The COsmic-ray Soil Moisture Observing System, Hydrol. Earth Syst. Sci. Discuss., 9, 4505-4551, doi:10.5194/hessd-9-45052012, 2012. 